\title{
Effects of Land Use Change on the Soil Organic Carbon and Selected Soil Properties in the Sultan Marshes, Turkey
}

\section{Selma Yaşar Korkanç ( $\nabla$ sykorkanc@ohu.edu.tr)}

Niğde Ömer Halisdemir University: Nigde Omer Halisdemir Universitesi

\section{Mustafa Korkanç}

Niğde Ömer Halisdemir University: Nigde Omer Halisdemir Universitesi

\section{Muhammet Hüseyin Mert}

Niğde Ömer Halisdemir University: Nigde Omer Halisdemir Universitesi

\section{Abdurrahman Geçili}

Niğde Ömer Halisdemir University: Nigde Omer Halisdemir Universitesi

\section{Yusuf Serengil}

İstanbul Üniversitesi-Cerrahpaşa Orman Fakültesi: Istanbul Universitesi-Cerrahpasa Orman Fakultesi

\section{Research Article}

Keywords: Sultan Marshes, land use change, SOC, carbon stock

Posted Date: November 17th, 2021

DOI: https://doi.org/10.21203/rs.3.rs-1001584/v1

License: (c) (i) This work is licensed under a Creative Commons Attribution 4.0 International License. Read Full License 


\section{Abstract}

This study aims the effects of land use changes on the carbon storage capacity and some soil properties of The Sultan Marshes was partially drained during the middle of the last century and converted to other land uses.

Undisturbed soil sampling was performed in different land use types (rangelands, shrubs, marsh, agriculture, and dried lake area) in the wetland area at depths of $0-50 \mathrm{~cm}$, and soil organic carbon (SOC), bulk density, and carbon stocks of soils for each land use type were calculated at $10 \mathrm{~cm}$ soil depth levels. Furthermore, disturbed soil samples were taken at two soil depths (0-20 cm and 20-40 cm), and the particle size distribution, $\mathrm{pH}$, electrical conductivity (EC), aggregate stability and dispersion ratio (DR) properties of the soils were analyzed. Data were processed using ANOVA, Duncan's test, and Pearson's correlation analysis.

The soil properties affected by land use change were SOC, carbon stock, pH, EC, aggregate stability, clay, silt, sand contents, and bulk density.

SOC and carbon stocks were high in rangeland, marsh, and shrub land, while they were low in agriculture and drained lake areas. As the soil depth increased, SOC and carbon stock decreased. The organic carbon content of the soils exhibited positive relationships with aggregate stability, clay, and carbon stock, while it showed a negative correlation with bulk density, $\mathrm{pH}$, and DR. The results showed that the drainage and conversion of the wetland caused a significant decrease in the carbon contents of the soils.

\section{Introduction}

Wetlands, the largest and effective carbon reservoirs in the world (IPCC 2005, Bedard-Haughn et al. 2006), are also the source of many ecosystem functions such as improving water quality, flood protection, and supporting biodiversity, and they are an important component of water and nutrient cycles (Mitra et al. 2005; Mitsch and Gosselink 2015). However, their roles as the atmospheric gas cycle and carbon pool are less acknowledged. It is effective to benefit from natural systems to try to control greenhouse gas emissions into the atmosphere. Although wetlands occupy a small area of 2-6\% in the world, they cover a significant part of terrestrial soil sinks that store carbon (Whiting and Chanton 2001; Stockmann et al. 2013). According to estimations, $20-30 \%$ of the $2,500 \mathrm{Pg}$ carbon in the world soils (Lal 2008) is accumulated in wetlands (Bridgham et al. 2006). Wetland functions depend on the strong relationships between wetland water and soils. Therefore, soil conditions are one of the most important and critical components of wetland intervention (improvement, restoration, etc.). Soil organic matter in wetlands is associated with various soil properties (Brady and Weil 2002), and it has functions such as controlling the hydrological properties of the soil, removing various contaminants from the water, carrying nutrients and elements necessary for plants (Craft et al. 1988; Hogan et al. 2004). The fertility, productivity, and quality of wetland ecosystems can be affected by soil organic carbon and nitrogen (Bruland 2003; Gebrehiwot et al. 2018).

Human activities may affect carbon stocks and greenhouse gas exchanges with the atmosphere in wetlands (Roulet 2000). Wetland drainage, reclamation, and conversion to agriculture, the conversion of saturated conditions (mostly anaerobic) to unsaturated conditions (aerobic) disrupt the important properties of wetlands and change the cycle of matter in the wetland system (Jacob and Otte 2003; Klove et al. 2010; Yang et al. 2013; Yuan et al. 2019; Zhu et al. 2021).

Although there are ecosystems with such a high ecological value in the world, wetlands are under extreme pressure to be converted to agricultural areas for the last century (Wang et al. 2006; Chen et al. 2015; Reis et al. 2017; Chemada et al. 2017, Mao et al. 2018). Global estimates show that the most significant conversions are $6 \%$ in temperate (Armentano and Menges 1986) and 50\% in tropical regions (Moser et al. 1996). Approximately $84 \%$ of human activities that cause land use change in wetlands, such as development and utilization for various purposes, are in Ramsar areas (Dugan and Jones 1992). Practices such as the drainage of wetlands, reclamation, and conversion to agriculture may cause a rapid decrease in soil organic matter in the cultivation zone (Oehl et al. 2004; Zhang et al. 2007; Page and Dalal 2011). The decomposition and 
accumulation of soil organic carbon in wetlands affect the stability of the soil carbon pool and $\mathrm{CO}_{2}$ emissions (Santin et al. 2008).

Various studies have been recently carried out on land use changes in wetlands (Wang et al. 2002; Liu et al. 2004; Zhang et al. 2004; Bian and Lin 2005). However, such studies aim to analyze the dynamics of wetlands using remote sensing techniques, mostly in large areas, and collect data (Treitz and Rogan 2004). Efforts should be made to evaluate carbon storage changes with field sampling. However, since this is a challenge due to physical transportation and a large number of pools, many studies are required in different regions.

In Turkey, many wetlands have been degraded in the last century, and drainage for conversion to agriculture was the major reason. Especially between 1950-1970, 21 wetlands (93 582 ha) were completely drained by government agencies to open up agricultural areas, prevent flooding, and combat malaria. Seventeen wetlands, covering 143956 hectares of land, were left to dry due to interventions in the flood prevention and water regime regulations (Erdem 2004). The Sultan Marshes was selected as a study area because it is one of the most important and internationally attractive wetlands in our country, where the pressure of anthropogenic processes on wetlands is well observed. The Sultan Marshes was included in the Wetland of International Importance category according to the Ramsar Convention in 1994 and was included within the scope of national parks in 2006 (Meriç and Çağırankaya 2013). The Sultan Marshes consists of habitats with different characteristics such as fresh and saltwater ecosystems, wide marshes and swamp areas, meadows, valuable bird habitats, rangelands and steppe areas surrounding these areas (Karadeniz 2000). In the flora studies conducted between 2002-2004, 428 species belonging to 73 families were identified in the area, and 48 of them are endemic to Turkey (Aksoy 2004). This important ecosystem has been exposed to drainage activities since the 1950s, and dams and ponds were built on some of the feeding streams, and some parts were opened to agriculture. The wetland and its surrounding ecosystem experience various environmental problems such as drought, changes in the hydrological system, opening to agriculture, and reed cutting. Various studies have been conducted to the present day on the ecosystem features of the Sultan Marshes (Özesmi et al. 1993; Kiziroğlu 1998), its flora (Yıldırımlı and Öztekin 2000; Hamzaoğlu and Aksoy 2006), environmental problems (Somuncu 1987), the human and economic characteristics of the region (Tunçel 1994), and the culture-environment relationship (Karabaşa 2006). Previous studies conducted in the Sultan Marshes region are mostly ecological and hydrological studies (Dadaşer-Çelik et al. 2006; Dadaşer Çelik et al. 2007; Dadaşer Çelik et al. 2008a; Gürer 2004; Karadeniz 1995; Karadeniz 1997). Furthermore, recent studies aim to determine land use changes by remote sensing techniques (Dadaşer-Çelik et al. 2008b, Kesikoğlu et al. 2015; Sönmez and Somuncu, 2016 Dadaşer-Çelik and Jouma 2017), and no study that coincides with the subject of this study was encountered. The Land Use, Land Use Change and Forestry (LULUCF) sector of the IPCC strives to identify carbon changes resulting from land use changes and attempts to develop policies and recommendations to control and predict carbon emissions/removals (IPCC 2003, 2005, 2006, 2013). These issues are among the major points of recent studies on global climate change. If we know how much carbon is retained in wetland soils, we can better understand the role of these areas as a carbon pool and direct the conservation efforts of these valuable ecosystems (url 1). It is extremely important to determine the effects of land use changes in wetlands on soil organic carbon in revealing the reaction of wetlands in terms of organic matter cycle to human effects. It is absolutely necessary to have information about the effects of land use conversions on the physical and chemical properties of soils to make appropriate recommendations in terms of soil sustainability and agricultural productivity (Tufa et al. 2019).

There are uncertainties regarding the estimates of carbon storage in wetlands and the effects of land use conversions on this accumulation. Information on how many wetlands have been converted to various human uses on a global scale is quite insufficient, and country-level estimates are mostly lacking. Knowing the effects of land use changes on the carbon budget and the amount of carbon stored in different terrestrial ecosystems, such as the Sultan Marshes, will positively contribute to carbon management and the global carbon balance, and studies on sustainable ecosystem management in the world. The effects of wetlands on greenhouse gases in many areas under the human influence are largely unknown.

To contribute to these knowledge gaps, this study aims to reveal the effects of land use changes, one of the important interventions that threaten wetlands, on the carbon stock and some soil properties in the wetland and surrounding soils with 


\section{Materials And Methods \\ 2.1. Site description}

The Sultan Marshes is a wetland ecosystem in the Develi Basin within the boundaries of Kayseri province, with a surface area varying between 8000-13000 ha, depending on the season. Its altitude varies between 1070-1150 m. The Sultan Marshes is located between $38^{\circ} 12^{\prime} 14^{\prime \prime}-38^{0} 25^{\prime} 49^{\prime \prime}$ north latitudes and $35^{0} 09^{\prime} 20^{\prime \prime}-35^{0} 22^{\prime} 20^{\prime \prime}$ east longitudes (Fig. 1). Its average slope is $2 \%$ (DSI 1995; Gürer 2004). The Sultan Marshes has "semi-arid subtropical Mediterranean terrestrial" climate characteristics with cold winters and hot summers (Aksoy 2003; Karadeniz 1995). The annual mean temperature in the basin is $11^{\circ} \mathrm{C}$, and the long-term mean annual precipitation is $363 \mathrm{~mm}$ (Özesmi and Gürer 2003). The soils in the Develi Closed Basin are usually of alluvial character and exhibit salty and alkaline characteristics in some places (Ulusoy et al. 2003). Thick, dark-colored hydromorphic alluvial soils rich in organic matter are located in areas with temporary lakes and marshes (Topraksu General Directorate, 1984). In the southeast of the Develi Plain, there are brown calcareous soils around Musahacılı and Yerköy (Karadeniz,1995; Yıldız 2007). The lands in the Sultan Marshes Nature Protection Area are used for settlement, agriculture, and grazing purposes.

Agricultural areas are concentrated in the southern and northern parts of the plain, and agricultural products include sugar beet, sunflower, wheat, barley, and fruits (UDGP 2008-2012). Overgrazing damages flora and fauna around the Sultan Marshes (Fig. 2) (Özesmi and Gürer 2003). Some parts of this wetland have been subjected to land use changes in the form of opening to agriculture by draining for similar purposes mentioned above. In the studies conducted using remote sensing techniques in the Sultan Marshes and its immediate surroundings, it was stated that various changes occurred in the land use/cover of the study area from the past to the present (Sönmez and Somuncu 2016; Dadaşer-Çelik and Jouma 2017). In these studies, it was emphasized that especially agricultural activities increased significantly, and consequently, natural vegetation areas and water areas decreased.

\subsection{Experimental design and soil sampling}

Several interventions related to land use in the area have been collected from the literature and summarized as follows:

In 1940, based on the economic conditions of the period, drainage activities were initiated in the Sultan Marshes to combat malaria and open space for agricultural land. With its original name of that day, TOPRAKSU, with the Yahyalı-Yuları Village drainage and irrigation project, 440 hectares of land were drained and opened to agriculture (DSI 1970).

Approximately 1900 hectares of land drained in the Kuzey (Northern/Kepir) Marshes in the north in the 1950s were distributed to villagers by the state.

In 1965, drainage channels were opened between Kopçu Village and Kocahacılı Village with the Yahyalı-Kocahacılı irrigation and drainage project of TOPRAKSU to drain an area of 750 hectares.

Regarding the llyaslı-Yahyalı drainage facilities project handled by the General Directorate of State Hydraulic Works (DSI), the drainage channels extending from Ilyaslı village to the Güney (Southern) Marshes and from Karamadızı village to the Yahyalı-Yeşilhisar road were opened in 1962 and 1968, and a 240 ha area was dried (Gürer 2004; Yıldız and Gürer 2008).

According to this information, it is thought that the strongest intervention in the area was the opening of the wetland to agriculture by exposing it to drying activities, which began in the 1940s-1950s. Furthermore, according to the information obtained from the local people, some of these areas, which were drained for agricultural purposes, have turned into rangelands for many years due to low agricultural productivity. 
The collected information was checked by field studies, and land use patterns and soil sampling plots were determined. A completely randomized block design was selected as the sampling design. Land use types sampled according to the land conditions are as follows: 1. Rangeland areas 2. Shrubland areas, 3. Örtülüakar (southern) marshes, 4. Kepir (northern) marshes, 5. Lands that have been previously wetlands and opened to agriculture at different times (orchards and agricultural areas), 6. The dry-lake area formed by the withdrawal of water due to drought (Fig. 3).

The field studies and soil sampling were conducted in the summer and autumn months of 2019, starting from the autumn of 2018.

Three sampling plots were determined $(20 \times 30 \mathrm{~m})$ from each of the land use patterns, and from each sampling plot, samples of the soil with the undisturbed natural structure were taken with the help of sampling tubes from three points. Samples of the soil with the disturbed structure were obtained with the help of a hand earth auger at two depths $(0-20 \mathrm{~cm} ; 20-40 \mathrm{~cm})$ (Fig. 4). Although the soil sampling depth is specified as $30 \mathrm{~cm}$ in the IPCC (2006) for wetlands in carbon stock calculations, it was planned to take samples up to $50 \mathrm{~cm}$ to see the storage status in the subsoils and changes in the soil characteristics taken from different land use patterns. However, sampling up to $50 \mathrm{~cm}$ from some points could be made with sampling tubes for samples with the undisturbed natural structure during field studies, and sampling up to $50 \mathrm{~cm}$ from some of them could not be performed due to some negativities in soil conditions and field conditions (excessive wetness or dryness, excessively sticky soil, swamp, etc.). In such cases, soil sampling was performed up to $30 \mathrm{~cm}$ or up to a depth at which samples could be taken. In marshland area, soil samples were taken from shallow marshes due to negatively land conditions. These samples taken were preserved by taking the necessary protection measures and transported to the laboratory. Then, soil organic carbon, bulk density, and carbon stock were determined for each depth level by separating soil samples into $10-\mathrm{cm}$ levels in the laboratory.

The locations where soil sampling was performed were marked as regional according to their land use on the map (Fig. 1). Some descriptive characteristics and coordinates of the regions where soil sampling plots were taken are presented in Table 1. 
Table 1

Location and general site characteristics of the sampling plots

\begin{tabular}{|c|c|c|c|c|c|}
\hline Location & Land use & Latitude & Altitude & Grazing & Land cover and management applications \\
\hline Mustafabeyli & Cropland & $\begin{array}{l}38.15 \\
5921^{\circ}\end{array}$ & $\begin{array}{l}35.37 \\
2572^{\circ}\end{array}$ & - & $\begin{array}{l}\text { Apple orchard, } 3 \times 5 \mathrm{~m} \text {, soil tillage is available } \\
\text { between rows, cattle manure and chemical } \\
\text { fertilization available }\end{array}$ \\
\hline Karamadazı & Cropland & $\begin{array}{l}3818 \\
6056\end{array}$ & $\begin{array}{l}35.28 \\
4480\end{array}$ & - & $\begin{array}{l}\text { Apple orchard, } 3 \times 5 \mathrm{~m} \text {, soil tillage is available } \\
\text { between rows, cattle manure and chemical } \\
\text { fertilization available }\end{array}$ \\
\hline Yuları & Cropland & $\begin{array}{l}38.16 \\
6676^{\circ}\end{array}$ & $\begin{array}{l}35.33 \\
1716^{\circ}\end{array}$ & - & $\begin{array}{l}\text { Apple orchard, } 3 \times 5 \mathrm{~m} \text {, soil tillage is available } \\
\text { between rows, cattle manure and chemical } \\
\text { fertilization available }\end{array}$ \\
\hline Yuları & Rangeland & $\begin{array}{l}3817 \\
1227\end{array}$ & $\begin{array}{l}3533 \\
3031\end{array}$ & Yes & Couch grass, jungus, vegetation cover $45 \%$ \\
\hline Ovaçifliği & Rangeland & $\begin{array}{l}38.25 \\
2520^{\circ}\end{array}$ & $\begin{array}{l}35.18 \\
8597^{\circ}\end{array}$ & $\begin{array}{l}\text { Yes, } \\
\text { heavy }\end{array}$ & $\begin{array}{l}\text { Couch grass, salt cristals are available on the soil } \\
\text { surface, vegetation cover } 60 \% \text {, tuz kristalleri } \\
\text { mevcut }\end{array}$ \\
\hline $\begin{array}{l}\text { Between Ovaçifliğ } \\
\text { and Senirköy }\end{array}$ & Rangeland & $\begin{array}{l}38.22 \\
0076^{\circ}\end{array}$ & $\begin{array}{l}35.23 \\
3874^{\circ}\end{array}$ & $\begin{array}{l}\text { Yes, } \\
\text { heavy }\end{array}$ & $\begin{array}{l}\text { Couch grass, salt cristals are available on the soil } \\
\text { surface, vegetation cover } 30-60 \%\end{array}$ \\
\hline $\begin{array}{l}\text { Between Ovaçifliği } \\
\text { and Kuşçu }\end{array}$ & Rangeland & $\begin{array}{l}38.25 \\
1421^{\circ}\end{array}$ & $\begin{array}{l}35.17 \\
3702^{\circ}\end{array}$ & $\begin{array}{l}\text { Yes, } \\
\text { heavy }\end{array}$ & $\begin{array}{l}\text { Couch grass, salt cristals are available on the soil } \\
\text { surface, vegetation cover } 30-50 \%\end{array}$ \\
\hline Ovaçifliği & Shrubland & $\begin{array}{l}38.25 \\
4628^{\circ}\end{array}$ & $\begin{array}{l}35.18 \\
5355^{\circ}\end{array}$ & $\begin{array}{l}\text { Yes, } \\
\text { heavy }\end{array}$ & $\begin{array}{l}\text { Tamarix, couch grass, salt cristals are available on } \\
\text { the soil surface, vegetation cover } 60 \%\end{array}$ \\
\hline Ovaçifliği & Shrubland & $\begin{array}{l}38.24 \\
7067^{\circ}\end{array}$ & $\begin{array}{l}35.19 \\
5805^{\circ}\end{array}$ & $\begin{array}{l}\text { Yes, } \\
\text { heavy }\end{array}$ & $\begin{array}{l}\text { Tamarix, couch grass, salt cristals are available on } \\
\text { the soil surface, vegetation cover } 50 \%\end{array}$ \\
\hline Ovaçifliği & Marshland & $\begin{array}{l}38.25 \\
5875^{\circ}\end{array}$ & $\begin{array}{l}35.19 \\
1497^{\circ}\end{array}$ & $\begin{array}{l}\text { Yes, } \\
\text { heavy }\end{array}$ & $\begin{array}{l}\text { Phragmatis sp., Mean vegetation height: about } 1.5 \\
\text { m., vegetation density } 95 \%\end{array}$ \\
\hline $\begin{array}{l}\text { Between ilyaslı } \\
\text { and Musahacılı }\end{array}$ & Cropland & $\begin{array}{l}38.19 \\
0423^{\circ}\end{array}$ & $\begin{array}{l}35.31 \\
4616^{\circ}\end{array}$ & - & $\begin{array}{l}\text { Apple orchard, } 3 \times 5 \mathrm{~m} \text {, soil tillage is available } \\
\text { between rows, cattle manure and chemical } \\
\text { fertilization available }\end{array}$ \\
\hline $\begin{array}{l}\text { Between Illyaslı } \\
\text { and Yerköy }\end{array}$ & Cropland & $\begin{array}{l}38.18 \\
1732^{\circ}\end{array}$ & $\begin{array}{l}35.31 \\
5157^{\circ}\end{array}$ & - & $\begin{array}{l}\text { Apple orchard, } 3 \times 5 \mathrm{~m} \text {, soil tillage is available } \\
\text { between rows, cattle manure and chemical } \\
\text { fertilization available }\end{array}$ \\
\hline İlyaslı & Cropland & $\begin{array}{l}38.17 \\
3637^{\circ}\end{array}$ & $\begin{array}{l}35.31 \\
1094^{\circ}\end{array}$ & - & $\begin{array}{l}\text { Apple orchard, } 3 \times 5 \mathrm{~m} \text {, soil tillage is available } \\
\text { between rows, cattle manure and chemical } \\
\text { fertilization available }\end{array}$ \\
\hline $\begin{array}{l}\text { Between Senirköy } \\
\text { and Yeşilova }\end{array}$ & Cropland & $\begin{array}{l}38.21 \\
4443^{\circ}\end{array}$ & $\begin{array}{l}35.22 \\
5096^{\circ}\end{array}$ & - & $\begin{array}{l}\text { Sunflower, barley, cattle manure and chemical } \\
\text { fertilization available }\end{array}$ \\
\hline $\begin{array}{l}\text { Senirköy- } \\
\text { Ovaçiftliği -Yerköy }\end{array}$ & Cropland & $\begin{array}{l}3822 \\
0076\end{array}$ & $\begin{array}{l}3523 \\
8874\end{array}$ & - & $\begin{array}{l}\text { Sunflower, barley, cattle manure and chemical } \\
\text { fertilization available }\end{array}$ \\
\hline $\begin{array}{l}\text { Between Senirköy } \\
\text { and Musahacılı }\end{array}$ & Cropland & $\begin{array}{l}38.19 \\
3873^{\circ}\end{array}$ & $\begin{array}{l}35.26 \\
7758^{\circ}\end{array}$ & - & $\begin{array}{l}\text { Sunflower, barley, cattle manure and chemical } \\
\text { fertilization available }\end{array}$ \\
\hline $\begin{array}{l}\text { Between Senirköy } \\
\text { and Yeşilova }\end{array}$ & Cropland & $\begin{array}{l}38.21 \\
4848^{\circ}\end{array}$ & $\begin{array}{l}35.22 \\
7588^{\circ}\end{array}$ & - & $\begin{array}{l}\text { Sunflower, barley, cattle manure and chemical } \\
\text { fertilization available }\end{array}$ \\
\hline Çöl lake & Rangeland & $\begin{array}{l}38.46 \\
2289^{\circ}\end{array}$ & $\begin{array}{l}35.20 \\
4739^{\circ}\end{array}$ & $\begin{array}{l}\text { Yes, } \\
\text { heavy }\end{array}$ & $\begin{array}{l}\text { Yabani kekik, bitki ile kaplı alan \%25 tuz kristaleri } \\
\text { mevcut }\end{array}$ \\
\hline $\begin{array}{l}\text { Between } \\
\text { Yenihayat and } \\
\text { Sindelhöyük }\end{array}$ & Rangeland & $\begin{array}{l}38.31 \\
5898^{\circ}\end{array}$ & $\begin{array}{l}35.34 \\
9916^{\circ}\end{array}$ & $\begin{array}{l}\text { Yes, } \\
\text { heavy }\end{array}$ & $\begin{array}{l}\text { Vegetation cover } 15 \% \text {, grounwater level is near } \\
\text { surface }\end{array}$ \\
\hline
\end{tabular}




\begin{tabular}{|c|c|c|c|c|c|}
\hline Location & Land use & Latitude & Altitude & Grazing & Land cover and management applications \\
\hline Yenihayat & Drylake & $\begin{array}{l}38.29 \\
7806^{\circ}\end{array}$ & $\begin{array}{l}35.30 \\
6889^{\circ}\end{array}$ & Yes & $\begin{array}{l}\text { Vegetation cover } 15 \% \text {, grounwater level is near } \\
\text { surface. dried lake area }\end{array}$ \\
\hline $\begin{array}{l}\text { Between } \\
\text { Sindelhöyük and } \\
\text { Soysallı }\end{array}$ & Cropland & $\begin{array}{l}38.36 \\
3322^{\circ}\end{array}$ & $\begin{array}{l}35.38 \\
0662^{\circ}\end{array}$ & - & $\begin{array}{l}\text { Maize, sunflower, barley, cattle manure and } \\
\text { chemical fertilization available,There is a hard soil } \\
\text { layer up to } 15 \mathrm{~cm} \text { deep }\end{array}$ \\
\hline $\begin{array}{l}\text { Between } \\
\text { Sindelhöyük and } \\
\text { Kepir }\end{array}$ & Cropland & $\begin{array}{l}38.38 \\
6547^{\circ}\end{array}$ & $\begin{array}{l}35.31 \\
9973^{\circ}\end{array}$ & - & $\begin{array}{l}\text { Maize, sunflower, barley, cattle manure and } \\
\text { chemical fertilization available,There is a hard soil } \\
\text { layer up to } 15 \mathrm{~cm} \text { deep }\end{array}$ \\
\hline $\begin{array}{l}\text { Between } \\
\text { Sindelhöyük and } \\
\text { Kepir }\end{array}$ & Marshland & $\begin{array}{l}38.36 \\
4801^{\circ}\end{array}$ & $\begin{array}{l}35.33 \\
6495^{\circ}\end{array}$ & - & $\begin{array}{l}\text { Phragmatis sp., Mean vegetation height: about } 1.5 \\
\text { m., vegetation density } 90 \% \text {. Feding by Soysallı } \\
\text { freshwater source, }\end{array}$ \\
\hline
\end{tabular}

\subsection{Laboratory analysis}

The soil organic carbon, bulk density, carbon stock, $\mathrm{pH}$, electrical conductivity (EC), aggregate stability, particle size distribution (texture), and dispersion ratio (DR) of the soils were determined. Air-dried soil samples were passed through a 2 $\mathrm{mm}$ sieve. The $\mathrm{pH}$ and $\mathrm{EC}$ were measured in a 1: $5 \mathrm{H}_{2} \mathrm{O}$ soil-water mixture using a Hach-Lange multiparameter instrument.

The core method was used to find soil bulk density (Blake and Hartge 1986). The hydrometer method was used to determine particle size distribution (Bouyoucos 1962). The soil organic carbon (SOC) was determined using the Walkley-Black method (Walkley and Black 1934). The dispersion ratio was defined according to Middleton (1930). Aggregate stability was calculated according to Kemper and Rosenau (1986). The carbon stocks of the soils were calculated as follows:

SOCs $=$ SOC $\times$ soil depth $x$ bulk density $x 10.000$ (1) (Pluske et al. 2013)

\subsection{Statistical design}

Experimental design factors were sampling depth ((0-10 (1 st depth), 10-20 (2nd depth) and 20-30 cm (3rd depth), 30-40 cm (4th depth), 40-50 cm (5th depth) for SOC, bulk density, carbon stock and ((0-20 (1st depth), 20-40 (2nd depth) for the other soil properties and land use (rangeland, cropland, shrubland, marshland, and dry-lake area). IBM SPSS Statistics version 24.00 was used to perform statistical analyses. The analysis of variance (ANOVA) was conducted to reveal the effects of land use and soil depth on soil properties, and Duncan's test $(a=0.05)$ was used to determine significant averages. Pearson's correlation analysis was conducted to determine the correlations between soil properties $(a=0.05)(Z a r 1996)$.

\section{Results And Discussion}

Descriptive statistics regarding the general characteristics of the study area soils are presented in Table 2. The results of the analysis of variance for soil depth and land use factors and their interactions are shown in Table 3. Furthermore, the results of Pearson's correlation analysis showing the relationships between soil properties are presented in Table 4. 
Table 2

Some descriptive statistics of general soil properties in the study site

\begin{tabular}{|llllll|}
\hline Soil property & N & Minimum & Maximum & Mean & Standard deviation \\
\hline SOC \% & 309 & 0.09 & 7.41 & 2.00 & 1.65 \\
\hline Carbon stock t/ha & 309 & 0.18 & 69.81 & 21.17 & 16.77 \\
\hline Bulk density g/cm ${ }^{3}$ & 309 & 0.22 & 2.54 & 1.26 & 0.36 \\
\hline $\mathrm{pH}$ & 268 & 7.51 & 9.51 & 8.48 & 0.46 \\
\hline Electrical conductivity $\mathrm{HS} / \mathrm{cm}$ & 268 & 105.00 & 16170.00 & 2143.31 & 2597.30 \\
\hline Aggregate stability \% & 268 & 0.52 & 100.00 & 29.81 & 18.49 \\
\hline Dispersion ratio \% & 268 & 5.20 & 122.83 & 43.10 & 17.22 \\
\hline Clay \% & 268 & 1.08 & 100.00 & 34.40 & 23.86 \\
\hline Silt \% & 268 & 0.00 & 81.23 & 30.43 & 17.18 \\
\hline Sand \% & 268 & 0.00 & 87.79 & 35.16 & 18.48 \\
\hline
\end{tabular}

Table 3

ANOVA results for testing land use, soil depth and their interactions on selected soil properties

\begin{tabular}{|c|c|c|c|c|c|c|c|c|c|c|c|}
\hline $\begin{array}{l}\text { Source } \\
\text { of } \\
\text { variation }\end{array}$ & & SOC & CS & BD & $\mathrm{pH}$ & EC & AS & DR & Clay & Silt & Sand \\
\hline \multirow{2}{*}{$\begin{array}{l}\text { Land } \\
\text { use }\end{array}$} & $P$ & 0.000 & 0.000 & 0.023 & 0.000 & 0.000 & 0.000 & 0.000 & 0.000 & 0.000 & 0.000 \\
\hline & $\begin{array}{l}\mathrm{F} \\
\text { values }\end{array}$ & 10.134 & 12.078 & 2.870 & 42.401 & 28.206 & 6.424 & 32.341 & 65.575 & 13.211 & 33.688 \\
\hline \multirow{2}{*}{$\begin{array}{l}\text { Soil } \\
\text { depth }\end{array}$} & $P$ & 0.000 & 0.000 & 0.000 & 0.015 & 0.699 & 0.908 & 0.008 & 0.003 & 0.270 & 0.025 \\
\hline & $\begin{array}{l}\text { F } \\
\text { values }\end{array}$ & 7.264 & 10.431 & 13.877 & 5.952 & 0.150 & 0.013 & 7.177 & 9.131 & 1.222 & 5.105 \\
\hline \multirow{2}{*}{$\begin{array}{l}\text { Land } \\
\text { usexSoil } \\
\text { depth }\end{array}$} & $P$ & 0.454 & 0.909 & 0.833 & 0.010 & 0.005 & 0.419 & 0.387 & 0.592 & 0.288 & 0.045 \\
\hline & $\begin{array}{l}F \\
\text { values }\end{array}$ & 0.998 & 0.525 & 0.624 & 3.365 & 3.870 & 0.979 & 1.040 & 0.700 & 1.255 & 2.478 \\
\hline
\end{tabular}


Table 4

Correlations between selected soil properties

\begin{tabular}{|c|c|c|c|c|c|c|c|c|c|c|}
\hline & SOC & CS. & BD & $\mathrm{pH}$ & EC & AS. & Clay & Silt & Sand & DR \\
\hline soc & 1 & & & & & & & & & \\
\hline CS & $0.840^{\star *}$ & 1 & & & & & & & & \\
\hline BD & $-0.454^{\star \star}$ & -0.083 & 1 & & & & & & & \\
\hline $\mathrm{pH}$ & $-0.188^{\star \star}$ & -0.143 & $0.179^{\star \star}$ & 1 & & & & & & \\
\hline EC & -0.025 & 0.010 & $0.136^{*}$ & $0.270^{\star \star}$ & 1 & & & & & \\
\hline AS & $0.202^{\star \star}$ & $0.143^{*}$ & -0.114 & -0.077 & 0.019 & 1 & & & & \\
\hline Clay & $0.166^{\star \star}$ & $0.166^{\star \star}$ & 0.022 & 0.085 & -0.046 & $0.174^{\star \star}$ & 1 & & & \\
\hline Silt & -0.117 & -0.105 & $0.121^{*}$ & 0.066 & $0.399^{\star *}$ & -0.100 & $-0.638^{\star \star}$ & 1 & & \\
\hline Sand & -0.106 & -0.116 & $-0.141^{*}$ & $-0.171^{\star \star}$ & $-0.311^{\star \star}$ & $-0.132^{*}$ & $-0.698^{\star \star}$ & -0.106 & 1 & \\
\hline DR & $-0.125^{\star}$ & -0.100 & 0.097 & $0.297^{\star \star}$ & $0.569^{\star \star}$ & 0.028 & 0.013 & $0.208^{\star \star}$ & $-0.210^{\star \star}$ & 1 \\
\hline \multicolumn{11}{|c|}{$\star \star$ Correlation is significant at the 0.01 level (2-tailed). } \\
\hline \multicolumn{11}{|c|}{ * Correlation is significant at the 0.05 level (2-tailed). } \\
\hline
\end{tabular}

\subsection{Soil organic carbon}

The SOC in the study area varied between $0.09-7.41 \%$ (Table 2). According to different land use types, the average SOC can be listed in descending order as rangeland>marshland>shrubland $>$ cropland $>$ dry-lake area (Fig. 5). The average SOC content of the study area was statistically significantly affected by the land use change $(P<0.05)($ Table 3$)$. While the organic carbon content of rangeland and marshland soils was statistically similar, it was different from other land use types. The SOC in the dry-lake area was lower and statistically different from other land uses. The SOC in the shrubland and cropland also showed statistical similarity (Fig. 5). The SOC content in rangeland, marshland, and shrubland areas was found to be higher than other land uses.Similar to our study, Tangen and Bansal (2020) found approximately 6\% SOC in inner natural marshland soil at 0-15 cm depth The high SOC content in the rangeland, marshland and shrubland areas could be explained by the continuous input of organic material from their aboveground plant biomass than the other land uses. The amount of organic carbon, nitrogen, and phosphorus in wetland soils depends on organic matter accumulation (Frolking et al. 2001; Avnimelech et al. 2001). Plants in the growth process affect organic carbon by changing the environment of the soil (Santin et al. 2008). In the study conducted by Compton and Boone (2000), high productivity and perennial flooding in the two marshes indicated the high rate of carbon and nutrient accumulation in wetland soils, leading to the formation of large amounts of organic residues in the soil and slow decomposition of soil organic matter. According to the results of this study, the draining of the wetland and converting it to agriculture affected the SOC adversely. It is thought that the low SOC in the dry-lake area may be due to the decomposition of the organic matter in that region and the absence of new organic matter input in its place.

The statistical analysis results according to the soil depth factor showed that the average SOC was affected by the change in soil depth $(\mathrm{P}<0.05)$ (Table 3). As the soil depth increased, SOC decreased. The SOC contents at the 1 st and 2 nd depth levels were $2.62 \%$ and $2.05 \%$, respectively, and statistically similar, higher, and different from other depths (Fig. 5). The SOC at the 
2nd, 3rd, and 4th depth levels was statistically similar. The SOC at the 5th depth layer was both the lowest and different from the other depths (Fig. 5).

As in this study, Luo et al. (2011) determined the highest SOC values at the depth level of 0-10 cm. It was recorded that the SOC decreased considerably at depths below $20 \mathrm{~cm}$. The distribution of plant roots in our sampling plots decreased with the increasing soil depth. This distribution explains the high amount of organic matter from plant biomass and belowground biomass in the topsoil (Dong et al. 2010). Again, Zhu et al. (2021) stated that the organic matter was the highest in soybean fields at $20-40 \mathrm{~cm}$ and $40-60 \mathrm{~cm}$ depth and at 0-20 $\mathrm{cm}$ in the drained wetland. They found that organic matter varied significantly depending on the depth in only natural wetlands and drained wetlands. In addition, Xia et. al. (2021) reported that SOC decreased with increasing soil depth.

In our study, the SOC content was lower in croplands compared to rangelands and marshlands. Wetland losses for agricultural purposes reduce SOC and carbon sequestration (Wang et al. 2010; Liu et al. 2019). Tillage activities disrupt the underlying ecosystem and expose it to aerobic aeration, increase the organic matter decomposition rate, and cause a decrease in the organic matter content of the soils (Reicosky and Lindstrom 1993; Gesch et al. 2007). The reason for the higher organic carbon content in the cropland compared to the northern marshland, even a little, may be the use of animal manure. Indeed, fertilization and tillage affect soil chemical properties (Gesch et al. 2007; Wright et al. 2007). Changes in water conditions in wetlands due to drainage activities may affect the accumulation of organic matter in the wetland. Wetland drainage decreases wetland productivity and accelerates the decomposition of more organic matter by ensuring its contact with air (Page and Dalal 2011). In a study conducted in Northeast Germany, it was stated that the organic carbon loss in a peat field drained 40 years ago was $37 \%$ (Kluge et al. 2008). Again, in a study in the Sanjiang Plateau in China, it was stated that deterioration in water-temperature conditions could accelerate decomposition, agricultural production activities might also cause a sharp decrease in the amount of organic matter returned to the soil, and this might cause a significant loss in SOC and nutrients in the cultivated areas (Song et al. 2004).

The SOC was positively correlated with aggregate stability, clay and carbon stock and negatively correlated with $\mathrm{pH}, \mathrm{DR}$, and bulk density (Table 4). Likewise, Luo et al. (2011) and Xia et al. (2021) noted that bulk density affected the organic carbon accumulation of the soil. Low bulk density makes the soil looser and ensures better permeability and better water holding capacity. This creates the desired environment in terms of organic carbon accumulation (Sakin 2012). Similar to the results of this study, Gebrehiwot et al. (2018) and Adesuyi et al. (2019) also found a negative correlation between soil pH and organic carbon. Likewise, Zhang et al. (2011) noted that the mechanical composition of the soil, bulk density, salinity, and nutritional status could affect the dynamics of soil carbon since it would directly affect the capacity of vegetation.

\subsection{Carbon stocks}

The carbon stock of the soils varied between 0.18-69.81 ton/ha (Table 2). The average carbon stocks of the soils according to land use patterns were listed in descending order as rangeland>marshland>shrubland >cropland>dry-lake area (Fig. 5). As land use changed, the carbon stocks of the soils also changed statistically significantly (Table 3 ).

The carbon stocks of the soils in the rangeland were similar to the carbon stock measured in the marshland area but were higher and statistically different from the values measured in other land use soils. The carbon stocks of cropland and shrubland soils were statistically similar. Again, the carbon stocks of shrubland and marshland soils were statistically similar (Fig. 5).

The carbon stock of the soils changed at a statistically significant level according to the soil depth (Table 3). In general, as the soil depth increased, the carbon stock of the soils decreased (Fig. 5). The carbon stocks at the 1st, 2nd, and 3rd depths were similar to each other and different from the other depths. Again, the carbon stock at the 3rd and 4th depth levels was statistically similar. The carbon stocks of the 4th and 5th depths were also statistically similar (Fig. 5). The average carbon stock was the highest in the soils at the $1 \mathrm{st}$ and 2 nd depth layers (25.47 ton/ha, 25.75 ton/ha, respectively) and the lowest at the 5th depth layer (2.80 ton/ha) (Fig. 5). 
In the IPCC (2019) report, the default carbon stock values in hot temperate dry climate zones were reported to be 24 ton/ha in high-activity clay soils for a 30-cm soil depth and 74 ton/ha in wetland soils (IPCC 2019). In this study, the total carbon capacity stored in the $40-\mathrm{cm}$ soil column was 115.68 ton/ha in the rangeland, 82.41 ton/ha in the shrubland, 81.52 ton/ha in the marshland, 53.86 ton/ha in the cropland, and 24.74 ton/ha in the dry-lake area. In the Turkey Greenhouse Gas Inventory Report (2020), it was predicted that the soil of a wetland with the carbon stock of 36.37 ton/ha for the Central Anatolian steppe conditions would store 32.14 ton/ha of carbon 20 years after its conversion to cropland.

When a general evaluation was made, the highest carbon stock was found in rangeland, marshland, and shrubland soils. A relatively lower storage capacity was detected in the soils in the cropland and dry-lake area. When the dry-lake area is examined, it can be concluded that the soils here may have lost a large part of the stored carbon after drying. Carbon stock in the cropland is thought to be contributed by fertilization resulting from agricultural activities. The higher carbon stock in rangeland, shrubland, and marshland soils can be explained by the organic matter contribution provided by vegetation. These results show that human activities that do not have continuous vegetation, such as agricultural activities, affect the organic carbon and carbon stocks of the soil. The results of this study revealed the importance of protecting marshlands, rangelands, and shrublands, which are an important sink for the global carbon cycle, against human effects. Yang et al. (2013) reported that total organic carbon values in the topsoil were affected by land use changes. The researchers detected that organic carbon in natural wetlands (Humus wetland $(203.5 \mathrm{~g} / \mathrm{kg}$ ) and wet grassland $(59.2 \mathrm{~g} / \mathrm{kg}$ ) was higher than other land use patterns. They stated that draining the humus wetland caused a significant decrease in the SOC (52\%). The soil organic matter decreased by $45 \%$ in the drained wet grassland.

Lands, the use of which was changed after the draining of wetlands, started to store carbon again. It was concluded that the carbon in the dry-lake area, which lost its water lastly, was lost to a significant extent.

The carbon stock of the soils was positively correlated with aggregate stability, clay, and organic carbon content and negatively correlated with $\mathrm{pH}$ (Table 4).

\subsection{Bulk density}

The bulk density of the soils in the study area varied between $0.22-2.54 \mathrm{~g} / \mathrm{cm}^{3}$ (Table 2). According to land use patterns, the bulk density of the soils was listed in descending order as shrubland>cropland>dry-lake area>rangeland>marshland (Fig. 6). The average bulk densities of the soils were statistically significantly affected by the change in land use $(P<0.05)(T a b l e ~ 3)$. The average bulk density of the soils taken from the marshland differed statistically from the values determined in other land uses. The average bulk densities of the soils under the other four land uses were statistically similar (Fig. 6).

When examined in terms of soil depth, the bulk densities of the study area soils were statistically significantly affected by the change in soil depth (Table 3). The bulk density of the topsoil was lower and statistically different from the subsoils. In general, as the depth of the soil increased, the bulk density also increased (Fig. 6).

The reason for the low bulk density in marshlands can be explained by the continuous organic material input in these areas and, therefore, the higher amount of organic matter compared to the cropland. The close bulk density to the cropland in the rangeland and shrubland can be explained by the pressure of grazing on these areas. The higher bulk density in the cropland compared to the marshland and rangeland may be due to low organic matter and soil cultivation. Likewise, Tufa et al. (2019), Yitbarek et al. (2013), and Takele et al. (2014) found that the bulk density of agricultural soils in the topsoil was higher than the bulk density in the rangeland and forest areas.

The bulk density of the soils was positively correlated with $\mathrm{pH}, \mathrm{EC}$, and silt content and negatively correlated with sand content and SOC (Table 4). SOC is a property that controls bulk density and porosity. As the organic carbon content of the soil increased, its bulk density decreased.

\section{$3.4 \mathrm{pH}$}


The $\mathrm{pH}$ of the soils in the study area generally varied between 7.51-9.51 (Table 2). The average pH of the soils according to different land uses was listed in descending order as dry-lake area>shrubland>rangeland>cropland>marshland (Fig. 7). The $\mathrm{pH}$ of the soils was statistically significantly affected by changes in land use $(\mathrm{P}<0.05)($ Table 3$)$. The average $\mathrm{pH}$ values were similar in the soils taken from dry-lake and shrubland areas and were statistically different from the soils taken from other land use patterns. The average $\mathrm{pH}$ of the soils taken from cropland and marshland areas was similar and different from the soils taken from other land use patterns. The decrease in $\mathrm{pH}$ in cropland soils could be caused by the washing out or depletion of the basic cations in the soil or by nitrogen fertilization (Chauhan et al. 2014; Tilahun 2007). The average pH of rangeland soils differed statistically from other land use patterns (Fig. 7). It is thought that the low pH in the marshland may have been caused by the high organic carbon content and the humic acids formed in the environment as a result of the decomposition of the vegetative material (Dube and Chitiga 2011). The average pH of the topsoils was 8.43 , and that of the subsoils was 8.57 , and the $\mathrm{pH}$ varied statistically significantly according to the soil depth (Fig. 7, Table 3). The pH can be used as an indicator for the quality of wetland soils under different land uses in terms of assessing the degradation in wetland soils. Zhu et al. (2021) also reported that the $\mathrm{pH}$ of 0-20 cm significantly changed between land uses that were converted to natural, drained, soybean agricultural lands and later rice cultivation areas, but there was not a very significant change.

The $\mathrm{pH}$ properties of the soils were positively correlated with EC, DR, and bulk density and negatively correlated with sand, organic carbon, and carbon stock (Table 4). Similar to this study, Yang et al. (2013) reported that the pH values of soils were negatively correlated with the total organic carbon.

\subsection{Electrical conductivity (EC)}

In general, the electrical conductivity (EC) values of the soils taken from the study area were between 105-16170 $\mu \mathrm{S} / \mathrm{cm}$ (Table 2). The average EC values of the soils according to different land use patterns were listed in descending order as drylake area $>$ shrubland>rangeland>marshland>cropland (Fig. 7). EC was statistically significantly affected by the change in land use $(\mathrm{P}<0.05)($ Table 3$)$. The average EC values were statistically different in the soil samples taken from the rangeland from the EC values of the samples taken from other land use patterns. The average EC of cropland and marshland soils was similar but different from other land uses. Again, the average EC of the soils taken from the dry-lake and shrubland areas was similar, but both values were higher and statistically different from other land uses (Fig. 7). When the evaluation was made by considering only the soil depth factor, the average EC in the topsoils was determined to be $2013 \mu \mathrm{S} / \mathrm{cm}$ and 2083 $\mu \mathrm{S} / \mathrm{cm}$ in the subsoils, and it was statistically similar. In other words, the soil depth did not significantly affect $E C(P>0.05)$ (Table 3).

In the study area, the salinity problem was observed, especially in the soils in the rangelands, shrubland, and dry-lake area in the Ovaçiftliği region. During the field studies, salt crystals were found in some places on the soil profile and surface in these regions (Fig. 8). It is thought that this may be related to the groundwater level close to the land surface in these regions. It is considered that irrigated farming practices in cropland soils may have reduced soil salinity by washing the topsoils.

It was determined that EC was positively correlated with $\mathrm{pH}$, silt, $\mathrm{DR}$, and bulk density and negatively correlated with sand content (Table 4).

\subsection{Aggregate stability}

The aggregate stability values of the soils in the study area varied between $0.52-100 \%$ (Table 2). The average aggregate stability of the soils according to different land use patterns was listed in descending order as marshland>dry-lake area $>$ cropland $>$ rangeland $>$ shrubland (Fig. 9). The aggregate stability of the soils was statistically significantly affected by land use changes $(\mathrm{P}<0.05)$ (Table 3$)$. The average aggregate stability of the soils taken from the shrubland was different from the aggregate stability of the soils taken from other land use patterns (Fig. 9).

The aggregate stability of the soils taken from the marshland was similar to that of the soils taken from the cropland and dry-lake area and different from other land use patterns. Again, the aggregate stability of the soils taken from the rangeland 
was similar to the soils taken from cropland and dry-lake area and statistically different from other land uses (Fig. 9). It was observed that the aggregate stability decreased in the areas where agriculture and animal grazing were performed in comparison with the marshland and dry-lake area. Thus, Mainuri et al. (2013) noted that tillage reduced aggregate stability. It is thought that the lower aggregate stability in the shrubland may be due to the higher sand content of the soil. A negative correlation was found between the aggregate stability of the soils and the sand content in the correlation analysis (Table 4).

According to the soil depth, the average aggregate stability of the topsoils (32.62\%) was higher compared to the subsoils (31.02\%). However, this difference was not statistically significant (Table 3).

The aggregate stability of the soils was positively correlated with clay content, SOC, and carbon stock and negatively correlated with sand content (Table 4). Mainuri et al. (2013) found a positive correlation between aggregate stability and soil organic carbon. Thus, the high values mentioned in the marshland with the high clay and organic carbon content also confirm this. The high sand content and low clay content in the shrubland probably reduced the aggregate stability.

\subsection{Dispersion ratio (DR)}

The DR values of the soils in the study area varied between 5.20-123\% (Table 2). When evaluated in general, the fact that the soils in the study area have $\mathrm{DR}>15$ indicates that they are sensitive to erosion (Balcl, 1996). The DR values of the soils according to different land use patterns were listed in descending order as shrubland>dry-lake area $>$ marshland $>$ rangeland $>$ cropland (Fig. 9). Land use change statistically significantly affected the DR of the soils $(P<0.05)$ (Table 3). The DR values of cropland, dry-lake area, and shrubland soils were different from each other and other land use patterns. The average DR of rangeland and marshland soils was statistically similar (Fig. 9).

Soils that seem to be most sensitive to erosion were identified as shrubland and soils in the dry-lake area (Fig. 9).

When evaluated in terms of the soil depth, it was determined that the DR values (39.67\%) of the topsoils in the study area were lower and statistically significantly different than the subsoils $(46.53 \%)(P<0.05)$ (Fig. 9) (Table 3). The topsoils were more resistant to erosion than the subsoils.

According to the correlation analysis, DR was positively correlated with $\mathrm{pH}, \mathrm{EC}$, and silt content and negatively correlated with sand content and SOC (Table 4).

\subsection{Particle size distribution}

According to the evaluation made according to the International Soil Society triangle (Tommerup 1934), soils in the study area had the loam-clay texture in the cropland and marshland areas, the clay loam texture in the rangeland area, the loam texture in the shrubland area, and the clay texture in the dry-lake area.

\subsubsection{Clay}

The clay content of the soils varied between 1.08-100\% (Table 2). According to the land use patterns, the average clay contents were listed in descending order as dry-lake area>marshland>cropland>rangeland>shrubland (Fig. 10). The clay content of the soils was statistically significantly affected by the change in land use $(P<0.05)($ Table 3$)$.

The soils taken from cropland and marshland areas were similar in terms of clay content. However, the soils taken from other land uses were different. The clay content of the soils taken from shrubland, rangeland, and dry-lake areas was statistically different (Fig. 10).

According to the soil depth, the clay content of the topsoils (30.55\%) was lower and statistically different from the clay content of the subsoils (38.25\%) $(P<0.05)$ (Table 3, Fig. 10). 
The clay content of the soils was positively correlated with aggregate stability, SOC, and carbon stock and negatively correlated with silt and sand content (Table 4).

\subsubsection{Silt}

The silt content of the soils generally varied between $0-81.23 \%$ (Table 2). According to different land use patterns, the average silt contents of the soils were listed in descending order as shrubland $>$ rangeland $>$ cropland $>$ marshland $>$ dry-lake area (Fig. 10). The silt content of the soils in the study area changed statistically significantly as the land use changed $(P<0.05)$ (Table 3).

The average silt content of the soils in the dry-lake area was lower and statistically different from that determined in other land use patterns. The silt content of the shrubland soils was similar to the values in the rangeland soils, but it was statistically different from the silt content in other land use patterns. Again, the silt content of the marshland soils was statistically similar to the values determined in the cropland area, but it was different from other land use patterns (Fig. 10).

According to the soil depth factor, silt contents did not differ statistically in the topsoil (30.74\%) and subsoil (30.12\%) $(P>0.05)$ (Table 3).

It was determined that silt content was positively correlated with EC, DR, and bulk density and negatively correlated with clay content (Table 4).

\subsubsection{Sand}

The sand content of the soils varied between $0-87.79 \%$ (Table 2). According to different land use patterns, the average sand contents were listed as shrubland>rangeland>marshland>cropland $>$ dry-lake area (Fig. 10). The average sand content of the soils was statistically significantly affected by the change in land use $(P<0.05)($ Table 3$)$.

The average sand content of the soils taken from the dry-lake area, cropland, marshland, and shrubland areas differed statistically. The sand content of rangeland soils was statistically similar to that of marshland and shrubland soils and was different from the soils of other land uses (Fig. 10).

When the sand content was examined in terms of soil depth, it was high in the topsoils of the study area (38.70\%) and lower (31.62\%) in the subsoils. This difference was statistically significant $(P<0.05)$ (Table 3, Fig. 10).

The sand content of the soils was negatively correlated with EC, pH, aggregate stability, clay, DR, and bulk density (Table 4).

Abbasi et al. (2007) emphasized that the differences between the textures of soils in different land use patterns showed the effects of different utilization and management systems on the soil properties of land use patterns.

\section{Conclusion}

The changes in land use in and around the Sultan Marshes significantly affected the soil properties, including organic carbon stocks. The soil properties affected by land use changes were SOC, carbon stock, pH, EC, aggregate stability, sand, clay, silt content, and bulk density. The soil properties affected by the change in soil depth were SOC, carbon stock, clay, sand content, and bulk density. SOC and carbon stock were higher in rangeland, marshland, and shrubland areas, while they were low in cropland and dry-lake areas. As the soil depth increased, the SOC and carbon stock decreased. In the 40-cm soil column, the highest carbon stock was in rangeland, shrubland, and marshland areas. The organic carbon content of the soils was positively correlated with aggregate stability, clay and carbon stock and negatively correlated with $\mathrm{pH}, \mathrm{DR}$, and bulk density. The carbon stock of the soils was positively correlated with aggregate stability, clay, and soil organic carbon content and negatively correlated with $\mathrm{pH}$. The soils in the study area generally showed an alkaline reaction. The highest $\mathrm{pH}$ values were in the dry-lake area soils, while the lowest $\mathrm{pH}$ values were in the marshland soils. There was a salinity problem, especially in the soils in the rangeland areas around Ovaçiftliği and Lake Çöl, in the shrubland and dry-lake area soils. In terms of carbon 
storage, the rangeland soils in the study area served as an important sink. However, since rangeland and shrubland areas were under grazing pressure due to the intensity of cattle and ovine breeding, animal husbandry activities in the region should be carried out within the grazing plan. The protection and improvement of controlled livestock and vegetation are very important for sustainable carbon management. Organic matter contribution to the soil can be enhanced by the restoration of degraded rangelands.

Activities such as drainage, conversion to agriculture, and grazing, which are among the human activities in the study area, affected the soil properties significantly. The marshland soils were affected by human activities (such as drainage, opening to agriculture, and animal husbandry). The intensive use pressure, especially in the Northern Marshes, should be mitigated. Thus, the study results revealed that the carbon stock of the better preserved Southern Marshes was higher than the Northern Marshes, where the human effects were more intense. Marshland areas, just like rangeland areas, are one of the most important carbon storage areas that need to be protected and improved. Especially agricultural activities have adversely affected the carbon stocks of the soils. In terms of soil carbon management in the wetland, it is recommended to stop further conversions to agriculture. The existing agricultural areas can be maintained with good agricultural practices that protect and improve the organic matter content of the soil.

\section{Declarations}

\section{Acknowledgment}

This project was financially supported by the Scientific and Technological Research Council of Turkey (TUBITAK) with project number: 118Y277. The authors would like to thank ilker Karaca for his support during field studies.

\section{Author Contributions}

SYK developed, conseptualized and administrated the research; SYK, MK, AG, performed the field work and collected the data; AG \& MHM analysed the data in the laboratory; SYK\&MK wrote the manuscript, YS review\&edit the manuscript and supervised the research.

\section{Funding}

AG and MHM received fellowships from TUBITAK (Project number: 118Y277)

\section{Data availability}

The data that support the findings of this study are available on request from the corresponding author.

\section{Conflict of interest}

The authors declare no competing interests.

\section{Ethics Approval}

Not applicable.

\section{Consent to Participate}

Not applicable.

\section{Consent for Publication}

Not applicable 


\section{References}

1. Abbasi, M.K., Zafar, M., Khan, S.R. (2007). Influence of different land-cover types on the changes of selected soil properties in the mountain region of Rawalakot Azad Jammu and Kashmir. Nutr Cycl Agroecosyst, 78, 97-110.

2. Adesuyi, A.A., Njoku, K.L., Akinola, M.O., Olayinka, D.N., Jimoh, O.A. (2019). Spatial distribution, dynamics and mapping of the soil organic carbon and total nitrogen density estimates in Lagos lagoon wetlands. Eqa - Environmental quality / Qualité de l'Environnement / Qualità ambientale 32, 29-43.

3. Aksoy, A. (2004). Sultan Sazlığı Flora I., II., III. Ara Raporu ve Final Raporu, Sultan Sazlığı GEF-II Proje Yönetim Birimi, Kayseri.

4. Aksoy, A., Demirezen, D. (2003) Sultan Sazlığı ve Çevresindeki Sucul Ekosistemlerde Ağır Metal Kirliliğinin İncelenmesi. DPT Projesi.

5. Armentano, T.V., Menges, E.S. (1986). Patterns of change in the carbon balance of organic soil-wetlands of the temperate zone. J. Ecol. 74, 755-774.

6. Avnimelech, Y., Ritvo, G., Meijer, L.E., Kochba, M. (2001). Water content, organic carbon and dry bulk density in flooded sediments. Aquacult. Eng. 25 (1), 25-33.

7. Balcı, N. (1996). Toprak Koruması, İstanbul Üniversitesi Yayınları, No: 3947, Orman Fakültesi Yayın No: 439, ISBN:9754044236, İstanbul.

8. Bedard-Haughn, A., Yongbloed, F., Akkerman, J., Uijl, A., de Jong, E., Yates, T., Pennock, D. (2006). The effects of erosional and management history on soil organic carbon stores in ephemeral wetlands of hummocky agricultural landscapes. Geoderma 135, 296-306.

9. Bian, J.M., Lin, N.F. (2005). Application of the 3S technology on the landscape evolution in the wetland of lower reach of Huolin River Basin. J Jilin Univ. 35, 221-225.

10. Bouyoucos, G. (1962). Hydrometer method improved for making particle size analysis of soils. Agron. J. 54, 464-465.

11. Blake, G.R., Hartge, K.H. (1986). Bulk density. In: Klute, A., Ed., Methods of Soil Analysis, Part 1-Physical and Mineralogical Methods, 2nd Edition, Agronomy Monograph 9, American Society of Agronomy-Soil Science Society of America, Madison, 363-382.

12. Brady, N., Weil R. (2002). The Nature and Properties of Soils. 13th ed. Prentice Hall, Upper Saddle River, NJ.

13. Bridgham, S.D., Megonigal, J.P., Keller, J.K., Bliss, N.B., Trettin, C. (2006). The carbon balance of North American wetlands. Wetlands 26, 889-916.

14. Bruland, G.L., Hanchey, M.F., Richardson, C.J. (2003). Effects of agriculture and wetland restoration on hydrology, soils, and water quality of a Carolina bay complex. Wetlands Ecol. Manage. 11,141-156.

15. Chauhan, R.P., Pande, K.R., Thakur, S. (2014). Soil properties affected by land use systems in western Chitwan. Nepal. Int J Appl Sci Biotechnol. 2(3), 265-269.

16. Chemada, M., Kibret, K., Fite, T. (2017). Influence of different land use types and soil depths on selected soil properties related to soil fertility in Warandhab Area, Horo Guduru Wallaga Zone, Oromiya, Ethiopia. International Journal of Environmental Sciences and Natural Resources 4 (2), 555634.

17. Compton, J.E., Boone, R.D. (2000). Long-term impacts of agriculture on soil carbon and nitrogen in New England forest. Ecology 81 (8), 2314-2330.

18. Craft, C.B., Broome, S.W, Seneca, E.D. (1988). Nitrogen, phosphorus and organic carbon pools in natural and transplanted marsh soils. Estuaries, 11, 272-280

19. Dadaşer-Çelik, F., Stefan, H. G., Brezonik, P.L. (2006). Dynamic hydrologic model of the Örtülüakar Marsh in Turkey. Wetlands 26, 1089-1102.

20. Dadaşer-Çelik, F., Brezonik, P. L., Stefan, H. G. (2007). Hydrologic sustainability of the Sultan Marshes in Turkey. Water Int. 32 (5), 856-876. 
21. Dadaşer-Çelik, F., Brezonik, P.L., Stefan, H. G. (2008a). Agricultural and environmental changes after irrigation management transfer in the Develi Basin, Turkey. Irrig Drain Sys. 22, 47-66.

22. Dadaşer-Çelik, F., Bauer, M.E., Brezonik, P.L., Stefan, H.G. (2008b). Changes in the Sultan marshes ecosystem (Turkey) in satellite images 1980-2003, Wetlands 28 (3), 852-865.

23. Dadaşer-Çelik F., Jouma N. (2017). Spatiotemporal changes at the Sultan Marshes ecosystem (Turkey) from 1987 to 2013", Ekoloji 2017, Kayseri, Türkiye, 11-13 May 2017, 1-1.

24. Dong, H.F., Yu, J.B., Sun, Z.G., Mu, X.J., Chen, X.B., Mao, P.L., Wu, C.F., Guan, B. (2010). Spatial distribution characteristics of organic carbon in the soil-plant systems in the Yellow River estuary tidal flat wetland. Environ Sci., 31, (6), $1594-1599$.

25. DSI (1970). Develi Projesi Planlama Raporu, Su-Iş Proje ve Mühendislik ve Müşavirlik Bürosu, Ankara.

26. DSI. (1995). Kayseri Develi-Yeşilhisar Ovası Revize Hidrojeolojik Etüd Raporu. DSi XII. Bölge Müdürlüğü, Kayseri, 1-19.

27. Dube, T., Chitiga, M. (2011). Human impacts on macrophyte diversity, water quality and some soil properties in the Madikane and Dufuya Wetlands of Lower Gweru, Zimbabwe. Appl. Ecol. Environ. Res. 9(1):85-99.

28. Dugan, P.J., Jones, T.A. (1992). Ecological change in wetlands: a global overview, in: M. Moser, R.C. Prentice, J. van Vessem (Eds.), Waterfowl and Wetland Conservation in the 1990s: A Global Perspective, Proceedings of the IWRB Symposium, November, St Petersburg, Florida.

29. Erdem, O. (2004). Sulak Alanlar, Önemi, Temel Sorunları, Türkiye'nin Uluslararası Öneme Sahip Sulak Alanları”, Haber Ekspres Gazetesi, 28 Şubat.

30. Frolking, S., Roulet, N.T., Moore, T.M., Richard, P.J.H., Lavoie, M., Muller, S.D. (2001). Modeling northern peat land decomposition and peat accumulation. Ecosystems 4 (5), 479-498.

31. Gebrehiwot, K., Desalegn, T., Woldu, Z., Demissew, S., Teferi, E. (2018). Soil organic carbon stock in Abune Yosef afroalpine and sub-afroalpine vegetation, northern Ethiopia. Ecol.Process, 7, 6-14.

32. Gesch, R.W., Reicosky, D.C., Gilbert, R.A., Morris, D.R. (2007). Influence of tillage and plant residue management on respiration of a Florida Everglades histosol. Soil Tillage Res. 92, 156-166.

33. Gürer, İ. (2004). Kayseri Sultansazlığı Tabiatı Koruma Alanının Su Kullanım ve Yönetim Planlaması Araştırması. Son Rapor, Çevre ve Orman Bakanlığı, 32-54.

34. Gürer, İ., Yıldız, E. (2008). Türkiye'nin sulak alan politikalarına genel bir bakış: Sultan Sazlığı Sulak Alanı örneği. TMMOB 2. Su Politikaları Kongresi Bildiri Kitabı s:335-345, 20-22 Mart, Ankara.

35. Hamzaoğlu, E., Aksoy, A. (2006). Sultan Sazlığı bataklığı halofitik toplulukları üzerine fitososyolojik bir çalışma (iç̧ Anadolu-Kayseri). Ekoloji 15 (60), 8-15.

36. Hogan, D.M., Jordan, T.E., Walbridge, M.R. (2004). Phosphorus retention and soil organic carbon in restored and natural freshwater wetlands. Wetlands, 24, 573-585.

37. IPCC (2003). IPCC Special Report on Good Practice Guidance for Land Use, Land-Use Change and Forestry. Edited by Penman, J., Gytarsky, M., Hiraishi, T., Krug, T., Kruger, D., Pipatti, R., Buendia, L., Miwa, K., Ngara, T., Tanabe, K., Wagner, F., Institute for Global Environmental Strategies (IGES), Japan.

38. IPCC (2005). Special report on carbon dioxide capture and storage: Summary for policymakers. Approved by the 8th Session of IPCC Working Group III. IPCC, Montreal, Canada.

39. IPCC (2006). IPCC Guidelines for National Greenhouse Gas Inventories. Available at: http://www.ipcc-nggip.iges.or.jp/ public/2006gl/index.html. (Accessed: 10th, December 2020)

40. IPCC (2007). Climate Change 2007: The Physical Science Basis. Contribution of Working Group I to the Fourth Assessment Report of the Intergovernmental Panel on Climate Change, edited by Solomon, S. Qin, D. Manning, M. Marquis, M. Averyt, K. Tignor, M.M.B. Miller, H.L.Jr. Chen, Z. Cambridge University Pres, Cambridge.

41. IPCC (2013). Supplement to the 2006 Guidelines for National Greenhouse Gas Inventories: Wetlands. (2013) Available at: http:// www.ipcc-nggip.iges.or.jp/home/wetlands.html. (Accessed: 15th, November 2020) 
42. IPCC (2019). 2019 Refinement to the 2006 IPCC Guidelines for National Greenhouse Gas Inventories, Chapter Two: Generic Methodologies Applicable to Multiple Land Use Categories, https://www.ipcc-

nggip.iges.or.jp/public/2019rf/pdf/4_Volume4/19R_V4_Ch02_Generic\%20Methods.pdf (Accessed: 15th, September 2020)

43. Kemper, W.D., Rosenau. R.C. (1986). Aggregate Stability and Size Distribution, In A. Klute et al., Methods of Soil Analysis, Part 1. Physical and Mineralogical Methods, 425-442, 2nd Edition, Agronomy Monograph, Soil Science of America, Madison, USA.

44. Karabaşa, S. (2006). Kayseri Sultan Sazlığı'nda kültür-çevre Illişkisi. Ankara Üniversitesi Sosyal Bilimler Enstitüsü Sosyal Bilimler Çevre Anabilim Dalı Basılmamış Yüksek Lisans Tezi, Ankara.

45. Karadeniz, N. (1995). Sultansazlığı örneğinde ıslak alanların çevre koruma açısından önemi üzerinde bir araştırma. Ankara Üniversitesi Fen Bilimleri Enstitüsü Peyzaj Mimarlığı Anabilim Dalı Basılmamış Doktora Tezi, Ankara.

46. Karadeniz, N. (1997). Sultan Marshes, Turkey: A new approach to sustainable wetland management. In: Nelson J.G., Serafin R. (eds) National Parks and Protected Areas. NATO ASI Series (Series G: Ecological Sciences), vol 40. Springer, Berlin, Heidelberg.

47. Karadeniz, N. (2000). Sultan Sazligi, Ramsar site in Turkey. Humedales Mediterra'neos 1,107-14.

48. Kesikoğlu, M.H., Atasever, U.H., Kesikoğlu, A., Karkınlı, A.E., Ozkan, C., Beşdok, E. (2015). Sultan Sazlığı Milli Parkı Ramsar bölgesi arazi örtüsünün belirlenmesi Boosting sınıflandırma yaklaşımı, TUFUAB VIII. Teknik Sempozyumu 21-23 Mayıs 2015 / Konya.

49. Kiziroğlu, İ. (1998). Anadolu'nun Doğal Cennetleri: Sultansazlığı, Popüler Bilim (Temmuz), 34-37.

50. Kløve, B., Sveistrup, T.E., Hauge, A. (2010). Leaching of nutrients and emission of greenhouse gases from peatland cultivation at Bodin, Northern Norway. Geoderma 154 (3-4), 219-232.

51. Kluge, B., Wessolek, G., Facklam, M., Lorenz M., Schwärzel, K. (2008). Long-term carbon loss and CO2-C release of drained peatland soils in northeast Germany Eur J Soil Sci. 59 (6), 1076-1086.

52. Lal, R. (2008). Carbon sequestration. Phil Trans R Soc B 363,815-830

53. Liu H., Zhang S., Li Z., Lu, X., Yang, Q. (2004). Impacts on wetlands of large-scale land-use changes by agricultural development: the Small Sanjiang Plain, China. Ambio.33 (6), 306-310.

54. Liu, X., Zhang, Y., Dong, G., Jiang, M. (2019). Difference in carbon budget from marshlands to transformed paddy fields in the Sanjiang Plain. Northeast China. Ecol. Eng. 137, 60-64.

55. Luo, X., Wang, L., Dun, M., Yang, J., Wang, Z. (2014). The accumulation and seasonal dynamic of the soil organic carbon in wetland of the Yellow River Estuary, China. Hindawi Publishing Corporation J Chem. Volume 2014, Article ID 408923, 8 pages.

56. Mao, D., Luo, L., Wang, Z., Wilson, M.C., Zeng, Y., Wu, B., Wu, J. (2018). Conversions between natural wetlands and farmland in China: a multiscale geospatial analysis. Sci Total Environ. 634, 550-560.

57. Meriç, T., Çağırankaya, S. (2013). Sulak Alanlar. Orman ve Su İşleri Bakanlığı, Doğa Koruma ve Milli Parklar Genel Müdürlüğü, Ankara.

58. Middleton, H.E. (1930). Properties of some soil which influence soil erosion. USDA TECH. Bull: 178.

59. Mitra, S., Wassmann, R., Vlek, P.L.G. (2005). An appraisal of global wetland area and its organic carbon stock. Curr Sci $88,25-35$

60. Mitsch, W.J., Bernal, B., Nahlik, A.M., Mander U., Zhang L., Anderson C.J., Jørgensen S.E., Brix, H. (2013).Wetlands, carbon, and climate change. Landscape Ecol 28, 583-597.

61. Mitsch, W.J., Gosselink, J.G. (2015). Wetlands. 5th edition. John Wiley \& Sons, New Jersey.

62. Moser, M., Prentice, C., Frazier, S. (1996). A global overview of wetland loss and degradation. In: Technical Session B of the 6th Ramsar Conference of Parties (COP). UNFCCC, New York, NY, USA and Brisbane, Australia. 
63. Oehl, F., Frossard, E., Fliessbach, A., Dubois, D., Oberson, A. (2004). Basal organic phosphorus mineralization in soils under different farming systems. Soil Biol Biochem. 36 (4), 667-675.

64. Özesmi, U., Gürer, İ. (2003). Sultan Sazlığı: Biodiversity and natural resources management pilot GEF-II project in Turkey. Journal of IUCN, USA.

65. Özesmi, U., Somuncu, M., Tunçel, H. (1993). Sultan Sazlığı ekosistemi. Ankara Üniversitesi Türkiye Coğrafyası Araştırma ve Uygulama Merkezi, Türkiye Coğrafyası Dergisi (2), 275-289.

66. Page, F K.L., Dalal, R.C. (2011).Contribution of natural and drained wetland systems to carbon stocks, CO2, N2O, and CH4 fluxes: an Australian perspective. Soil Res. 49 (5), 377-388.

67. Pluske, W., Murphy, D., Sheppard, J. (2013). Note on Total organic carbon. http://soilquality.org.au/factsheets/organiccarbon (Accessed::10.09.2019)

68. Reicosky, D.C., Lindstrom, M.J. (1993). Fall tillage method: Effect on shortterm carbon dioxide flux from soil. Agron J. 85,1237-1243.

69. Reis, V., Hermoso, V., Hamilton, S.K., Ward, D., Fluet-Chouinard, E., Lehner, B., Linke, S. (2017). A global assessment of inland wetland conservation status. Bioscience 67 (6), 523-533.

70. Roulet, N.T. (2000). Peatlands, carbon storage, greenhouse gases, and the Kyoto Protocol: Prospects and significance for Canada. Wetlands 20, 605-615.

71. Sakin, E. (2012). Organic carbon, organic matter and bulk density relationships in arid-semi arid soils in Southeast Anatolia region. Afr J Biotechnol. 11, (6), 1373- 1377.

72. Santin, C., Gonzalez-Perez, M., Otero, X.L., Vidal-Torrado, P., Macias, F., Alvarez, M.A. (2008). Characterization of humic substances in salt marsh soils under sea rush (Juncus maritimus). Estuar Coast Shelf Sci. 79, (3), 541-548.

73. Somuncu, M. (1987). Develi Ovasının Kuzey ve Batı Bölümünde Rüzgar Erozyonu Sorunu ile Alınması Gereken Önlemler Üzerine Bir Araştırma. Ankara Üniversitesi Sosyal Bilimler Enstitüsü Basılmamış Yüksek Lisans Tezi, Ankara.

74. Song, C.C., Wang, Y.Y., Yan, B.X., Lou, Y.J., Zhao, Z.C. (2004). The changes of the soil hydrothermal condition and the dynamics of C, N after the mire tillage. Chinese J Environ Sci. 25 (3), 150-154.

75. Sönmez, M.E., Somuncu, M. (2016). Sultansazlığı'nın alansal değişiminin sürdürülebilirlik açısından değerlendirilmesi. Türk Coğrafya Dergisi 66,1-10.

76. Stockmann U., Adams M.A., Crawford J.W., Field D.J., Henakaarchchi N., Jenkins M., Minasny B., McBratney A.B., de Courcelles V.de R., Singh K., Wheeler I., Abbott L., Angers D.A., Baldock J., Bird M., Brookes P.C., Chenu C., Jastrow J.D., Lal R., Lehmann J., O'Donnell A.G., Parton W.J., Whitehead D., Zimmerman M.J. (2013). The knowns, known unknowns, and unknowns of sequestration of soil organic carbon. Agric Ecosyst Environ. 164, 80-99.

77. Takele, L., Chimdi, A., Abebaw, A. (2014). Dynamics of soil fertility as influenced by different land use systems and soil depth in West Showa Zone, Gindeberet District, Ethiopia. Agriculture, Forestry and Fisheries 3 (6), 489-494.

78. Tangen, B. A., Bansal, S. (2020). Soil organic carbon stocks and sequestration rates of inland, freshwater wetlands: Sources of variability and uncertainty, Science of the Total Environment 749, 141444.

79. Tilahun, G. (2007). Soil fertility status as influenced by different land uses in maybar areas of South wello zone, North Ethiopia. Thesis M.Sc. Haramaya University, Ethiopia. 34-35p.

80. Tommerup, E.C. (1934). The Field Description of the Physical Properties of Soils, First Commission of Commission ISoil Physics-Of the International Society of Soil Science, pp. 155-158. International Society of Soil Science, Versailles, France.

81. Topraksu Genel Müdürlüğü (1984). Kayseri Illi Toprak Kaynağı Envanter Raporu. Tarım Bak. Yay. No: 183. Topraksu Gn. Md. Yay. No: 268. Ankara.

82. Treitz, P., Rogan, J. (2004). Remote sensing for mapping and monitoring land-cover and land-use change-an introduction. Prog Plann. 61 (4), 269-279. 
83. Tufa, M., Melese, A., Tena, W. (2019). Effects of land use types on selected soil physical and chemical properties: The case of Kuyu District, Ethiopia. Eurasian J Soil Sci. 8 (2), 94 - 109.

84. Tunçel, H. (1994). Develi İlçesinin Beşeri ve İktisadi Coğrafyası. Ankara Üniversitesi Sosyal Bilimler Enstitüsü Coğrafya Anabilim Dalı Beşeri ve İktisadi Coğrafya Bilim Dalı Basılmamış Doktora Tezi, Ankara.

85. Turkish Greenhouse Gases Inventory Report (2020). National Inventory Report for submission under the United Nations Framework Convention on Climate Change. Turkish Statistical Institute, April, 568 p. https://unfccc.int/documents/223580, (Accessed::20.10.2020).

86. UDGP (2008-2012). Sultan Sazlığı Milli Parkı ve Ramsar Alanı Uzun Devreli Gelişim Planı. Çevre ve Orman Bakanlığı Doğa Koruma ve Milli Parklar Genel Müdürlüğü.

87. Ulusoy, C.K., Yılmaz, M., Erginöz, E., Tursun, U.D. (2003). Develi (Kayseri) Belediyesi, Yeraltısuyu Kullanımı ÇED Ön Araştırma Raporu. İller Bankası Genel Müdürlüğü İçmesuyu Dairesi Başkanlığı, Ankara, 8, 12-19, 33-36, 59-66, 74.

88. url 1. https://www.saltmarshapp.com/science/\#science

89. Walkley, A., Black. I.A. (1934). An examination of the Degtjareff method for determining organic carbon in soils: Effect of variations in digestion conditions and of inorganic soil constituents. Soil Sci. 63, 251-263.

90. Wang, A.H., Zhang, S.Q., He, Y.F. (2002). Study on dynamic change of mire in Sanjiang Plain based on RS and GIS. Sci Geog Sin. 22, 636-640.

91. Wang, Z., Zhang, B., Zhang, S., Li, X., Liu, D., Song, K., Li, J., Li, F., Duan, H. (2006). Changes of land use and of ecosystem service values in Sanjiang Plain, Northeast China. Environ. Monit. Assess. 112 (1-3), 69-91.

92. Wang, L., Song, C., Song, Y., Guo, Y., Wang, X., Sun, X. (2010). Effects of reclamation of natural wetlands to a rice paddy on dissolved carbon dynamics in the Sanjiang Plain, Northeastern China. Ecol. Eng. 36 (10), 1417-1423

93. Whiting G.J, Chanton J.P. (2001). Greenhouse carbon balance of wetlands: methane emission versus carbon sequestration. Tellus B. 53, 521-528.

94. Wright, A.L., Dou, F., Hons, F.M. (2007). Crop species and tillage effects on carbon sequestration in subsurface soil. Soil Sci. 172, 124-131.

95. Xia, S, Song, Z, Li, Q, et al., (2021). Distribution, sources, and decomposition of soil organic matter along a salinity gradient in estuarine wetlands characterized by C:N ratio, $\delta 13 \mathrm{C}-\delta 15 \mathrm{~N}$, and lignin biomarker. Glob Change Biol. ; 27: 417434.

96. Yang, J., Liu, J., Hua, X., Lia, X., Wang, Y., Li, H. (2013). Changes of soil organic carbon, nitrogen and phosphorus concentrations under different land uses in marshes of Sanjiang Plain. Acta Ecol Sin. 33, 332-337.

97. Yıldırımlı, Ş., Öztekin, M. (2000). The Flora of Sultansazlığı (prov. Kayseri, Turkey). Bot Chr. (13), 389-408.

98. Yıldız, F.E. (2007). Kayseri- Sultan Sazlığı Sulak Alanı’nda Yeraltı ve Yerüstü Suları İlişkisinin Belirlenmesi. Gazi Üniversitesi, Fen Bilimleri Enstitüsü, İnşaat Mühendisliği Anabilim Dalı, Kasım, 218 s, Ankara.

99. Yıldız, F.E., Gürer, İ. (2009). An integrated water resources management of Develi Closed Basin in Kayseri - Türkiye. G.U. Journal of Science, 22 (3), 203-213.

100. Yitbarek, T., Gebrekidan, H., Kibret, K., Beyene, S. (2013). Impacts of land use on selected physicochemical properties of soils of Abobo Area, Western Ethiopia. Agriculture, Forestry and Fisheries 2 (5), 177-183.

101. Yuan, Y., Zhu, X., Mushet, D.M., Otte, M.L. (2019). Multi-element fingerprinting of waters to evaluate connectivity among depressional wetlands. Ecol. Indic. 97, 398-409.

102. Mainuri, Z.G., Owino, J. O. (2013). Effects of land use and management on aggregate stability and hydraulic conductivity of soils within River Njoro Watershed in Kenya. Int Soil Water Conser Res. 1, (2), 8087.

103. Zar, H.J. (1996). Biostatistical Analysis. 3rd Edition, Prentice Hall, New Jersey: 662 p.

104. Zhang, T., Mei, A. X., Cai, Y.L. (2004). Application of spot remote sensing image in landscape classification of Chongming Dongtan. Urban Environment \& Urban Ecology, 17, 45-47. 
105. Zhang, J.B., Song, C.C., Yang, W.Y. (2007). Effects of cultivation on soil microbiological properties in a freshwater marsh soil in Northeast China. Soil Tillage Res. 93 (1) 231-235.

106. Zhang, S., Wang, L., Hu, J., Zhang W., Fu, X., Le, Y., Jin, F. (2011). Organic carbon accumulation capability of two typical tidal wetland soils in Chongming Dongtan, China. J Environ Sci. 23 (1), 87-94.

107. Zhu, X., Yuan Y., Jiang, M. Song, C., Li, Y., Wang, G., Otte, M. L. (2021). Multi-element fingerprinting of soils can reveal conversion of wetlands to croplands. Sci Total Environ 752, 141997.

\section{Figures}

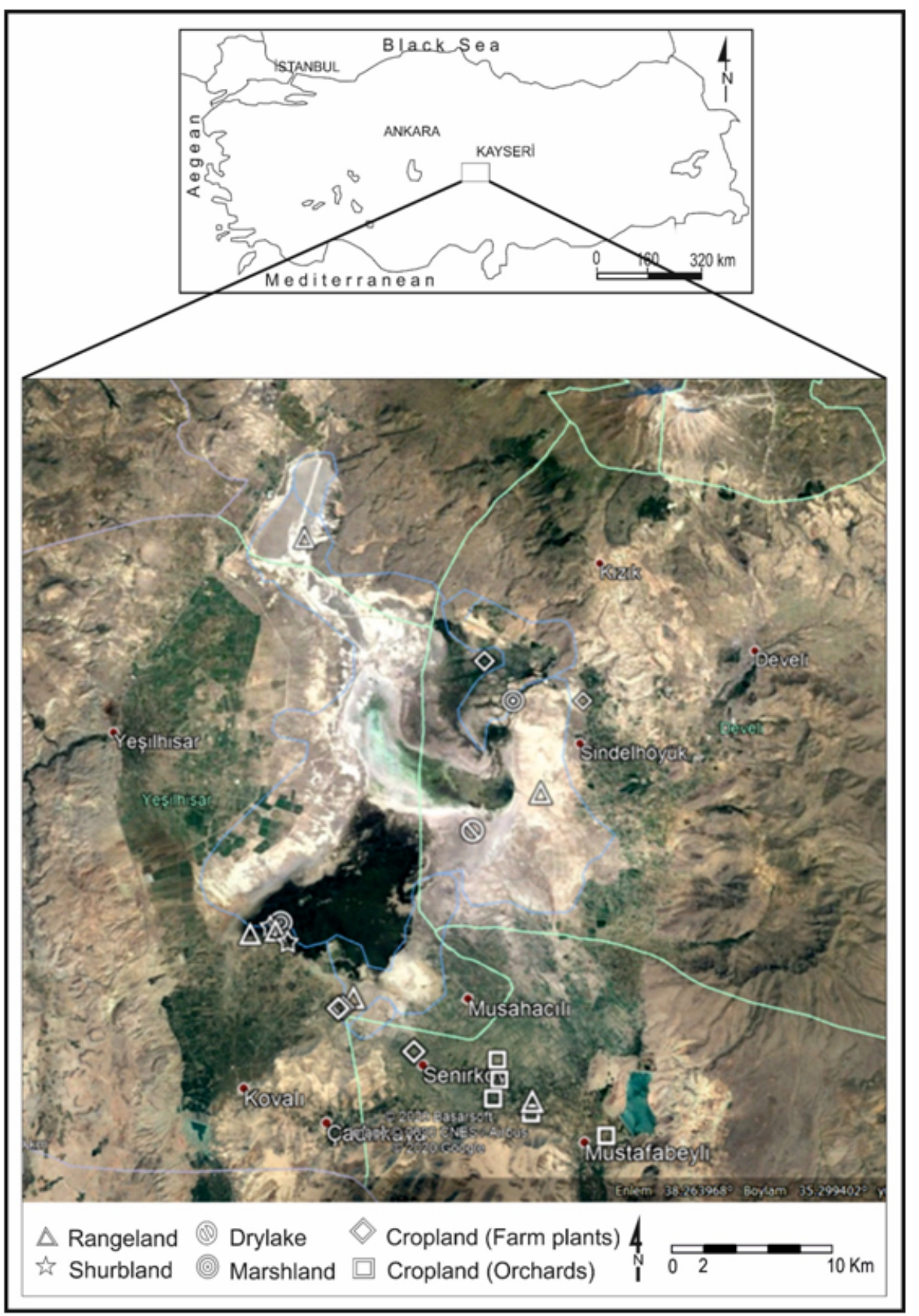

\section{Figure 1}

Study site and sampling locations 


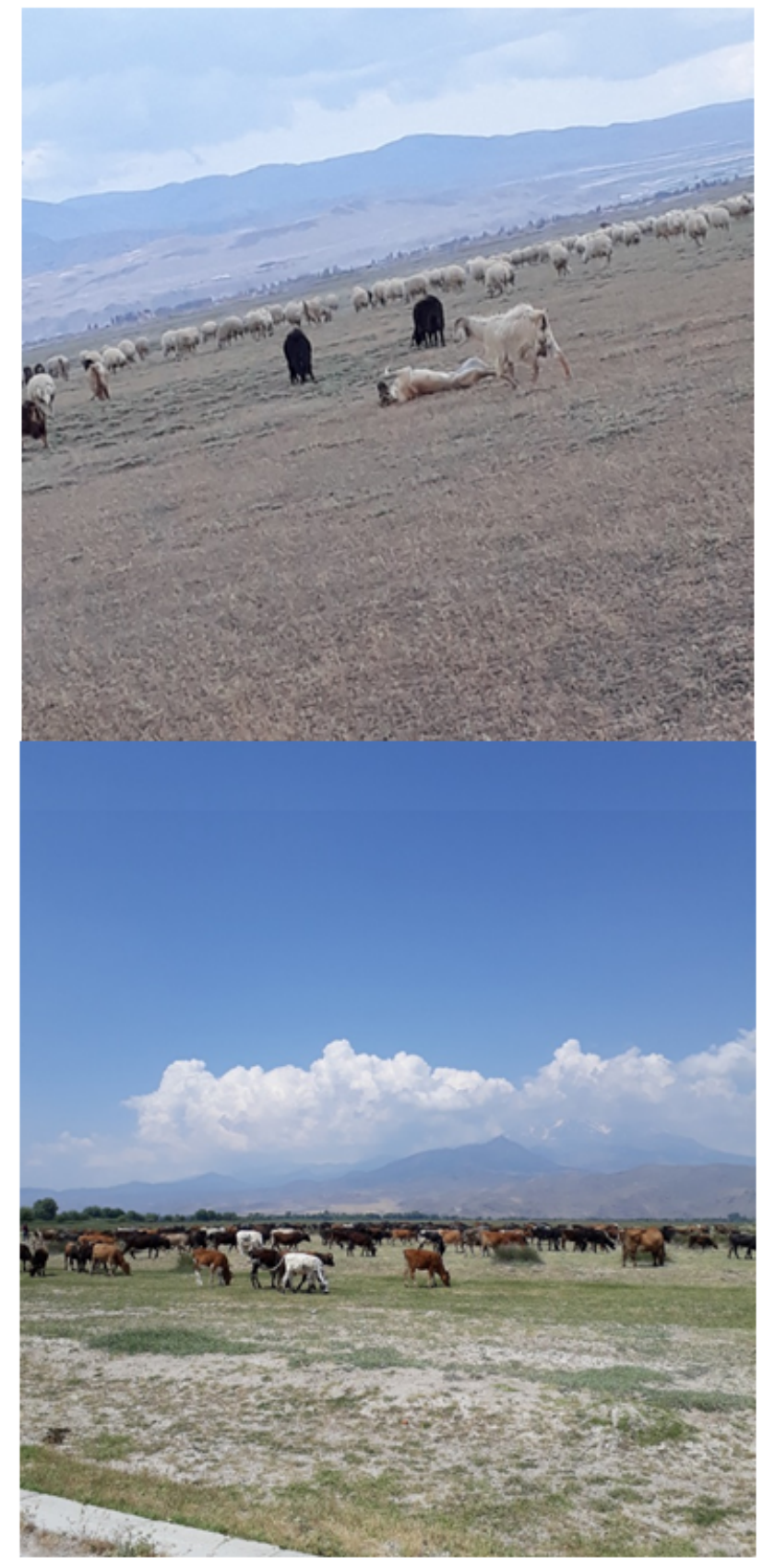

\section{Figure 2}

Animal grazing activities in the study site

A

\section{Figure 3}

Land use types in the study site a) Rangeland, b) Marshland, c) Shrubland d) Cropland e) Dry lake 

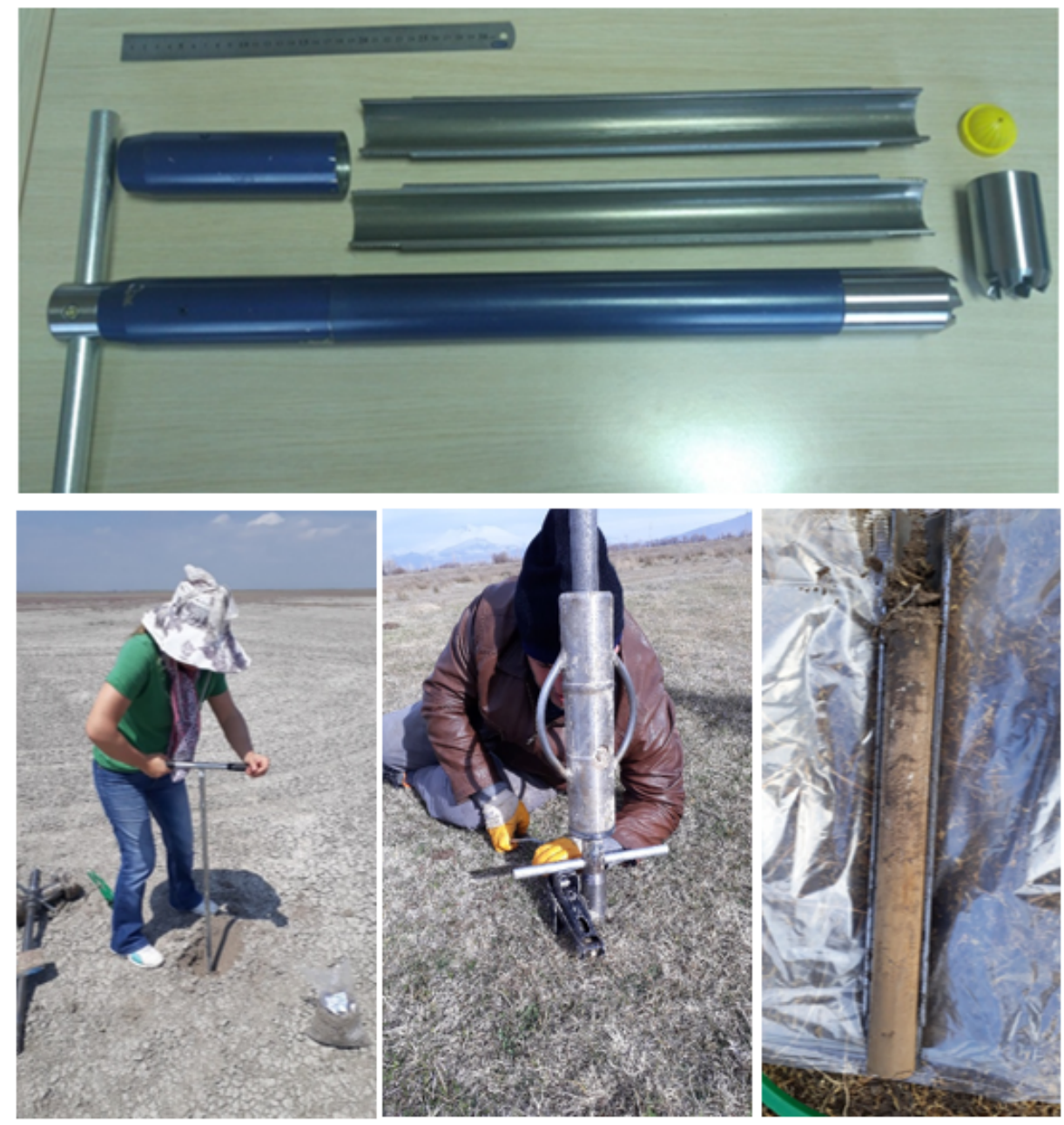

Figure 4

Views of undisturbed soil sampling equipment and disturbed and undisturbed soil sampling 

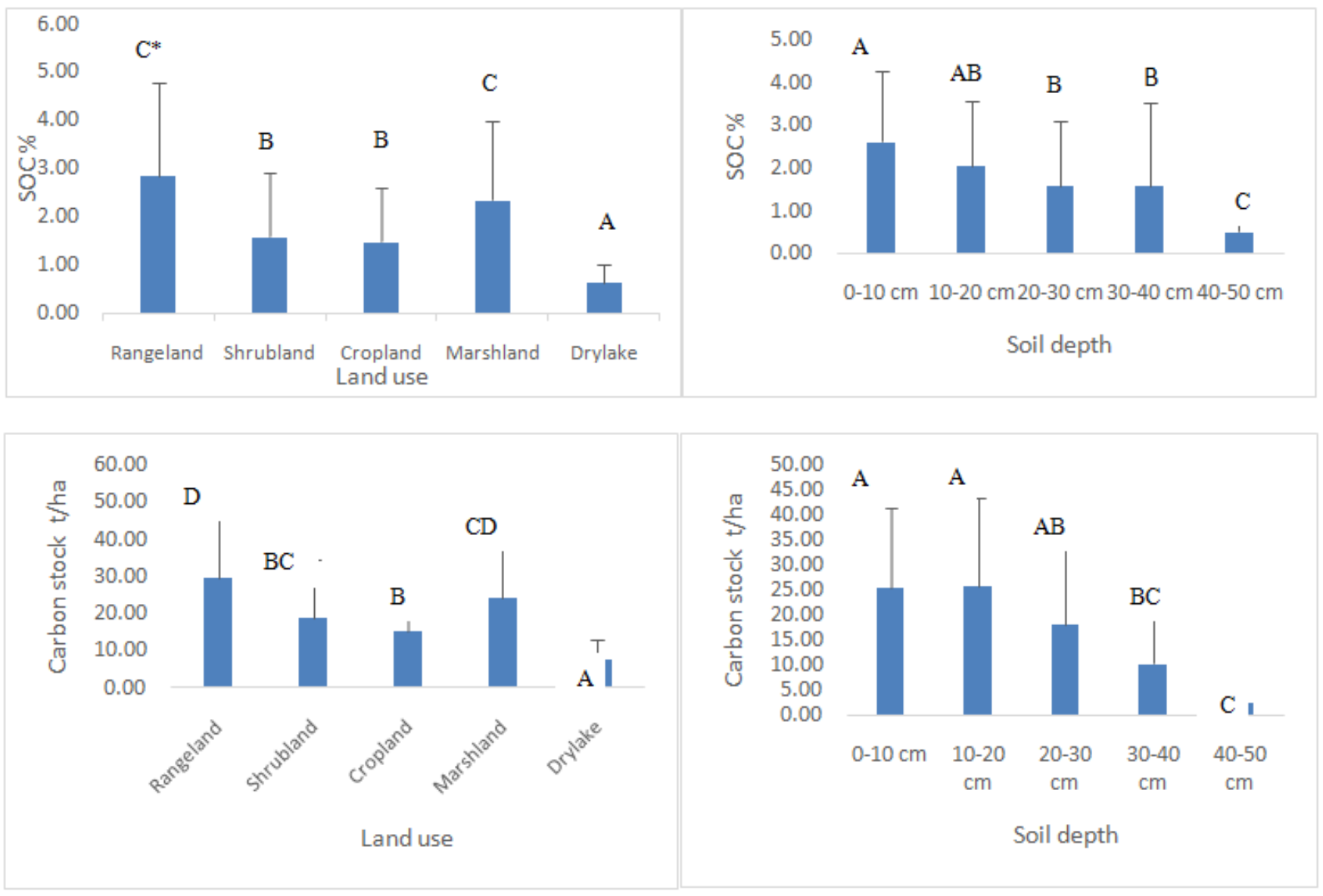

Figure 5

Changes in SOC and carbon stock according to land use and soil depth * Means with the different capital letter are significantly different at 0.05 level of significance $(P<0.05)$

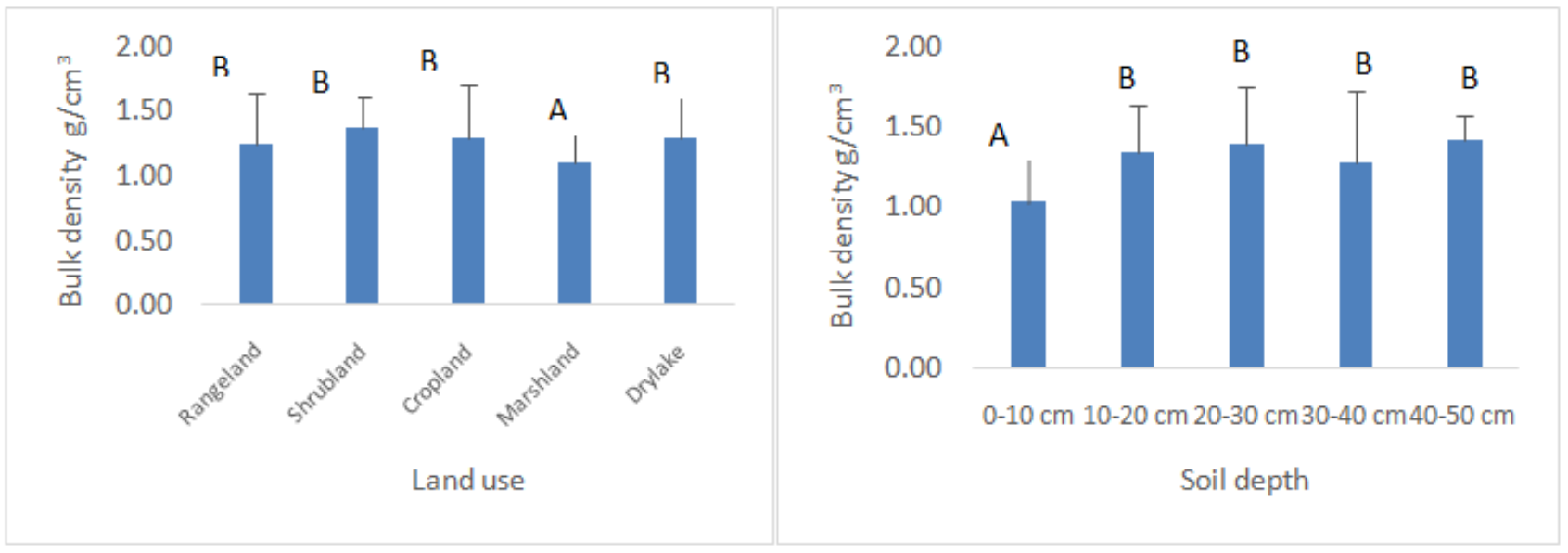

Figure 6

Changes in soil bulk density according to land use and soil depth 

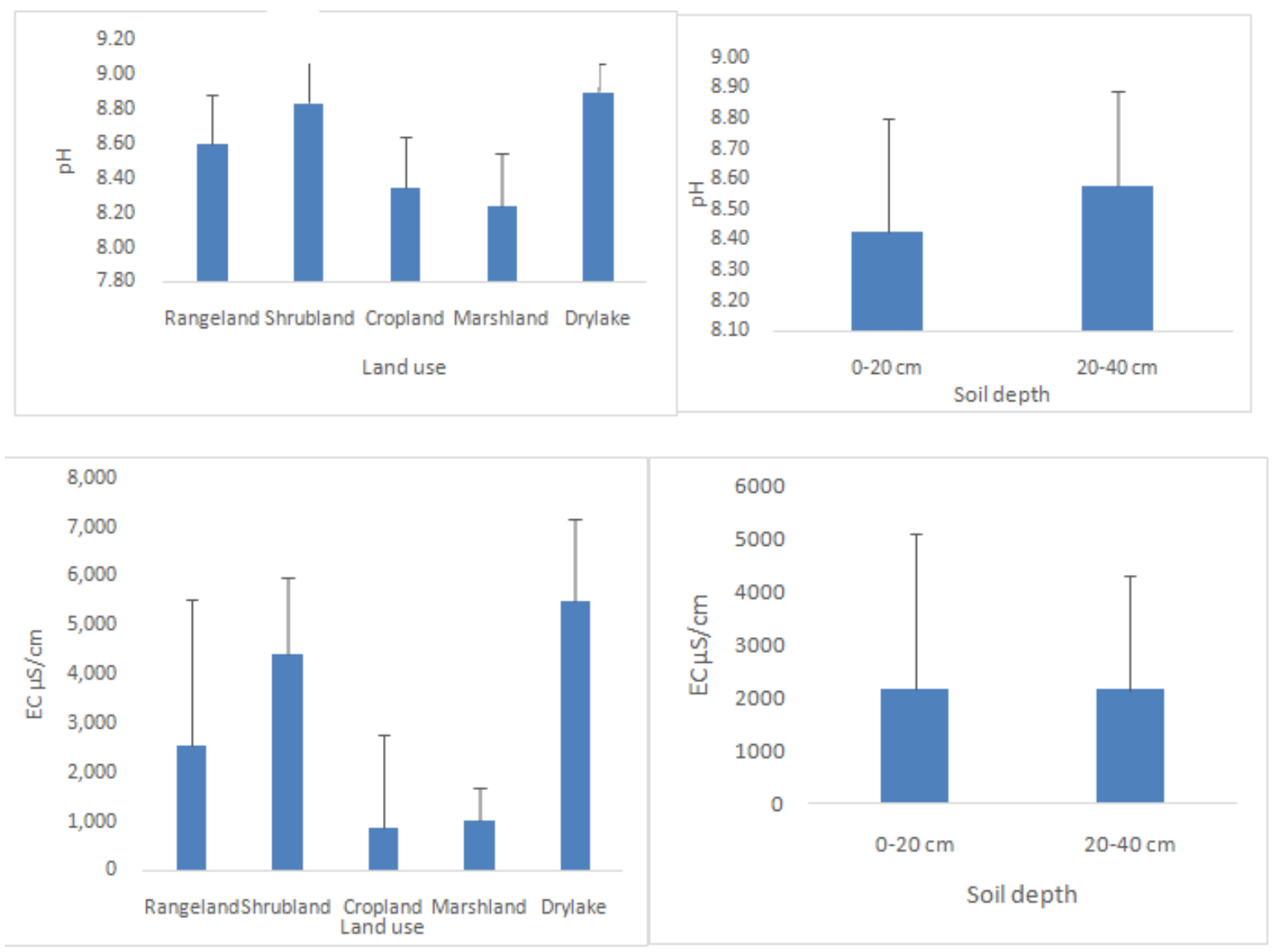

\section{Figure 7}

Changes in soil pH and EC according to land use and soil depth

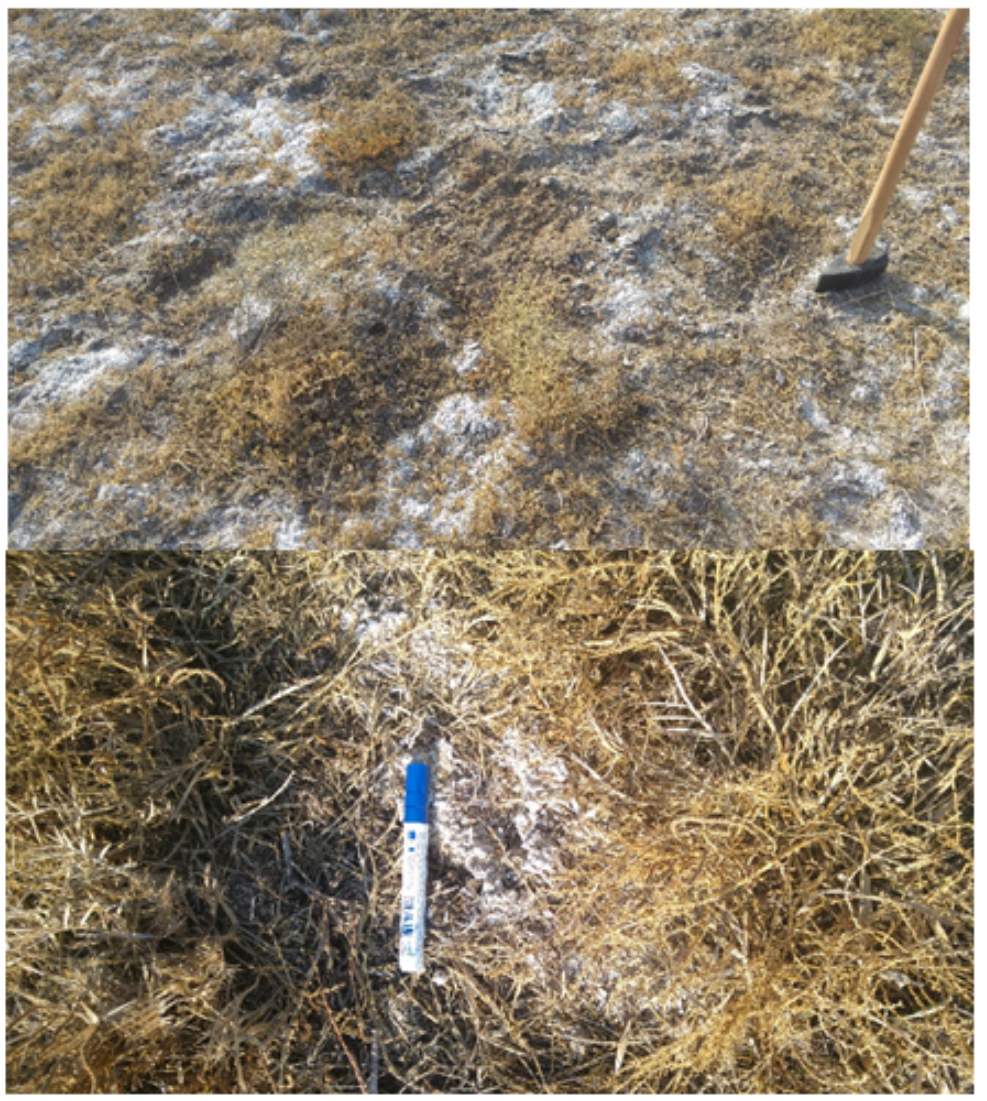


Figure 8

Salt crystals observed on soil surface in shrubland and rangeland
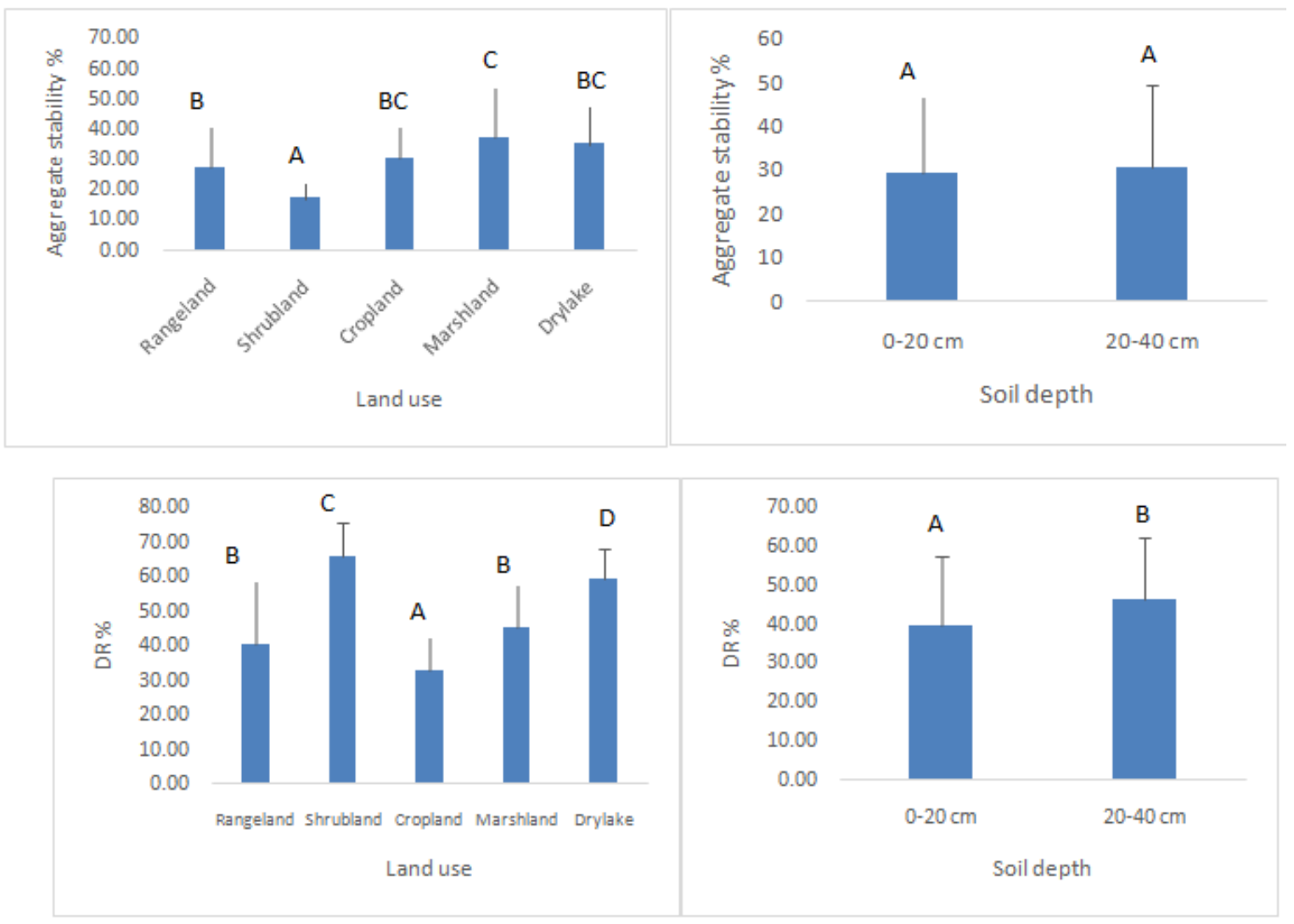

\section{Figure 9}

Changes in soil aggregate stability and DR according to land use and soil depth 

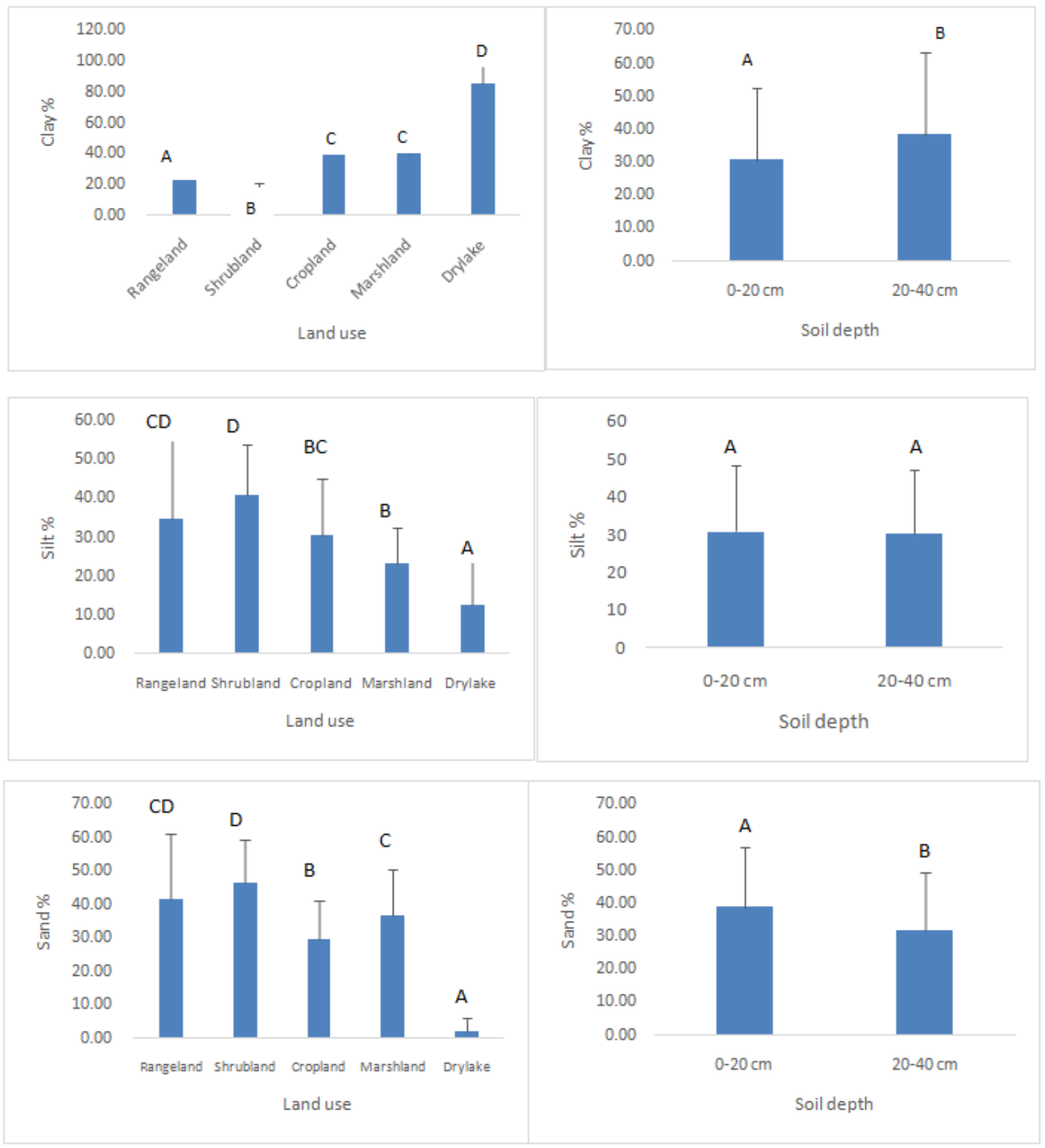

Figure 10

Changes in soil clay, silt and sand content according to land use and soil depth 